\title{
İkinci Adam ya da Kayda Değer Bir İstisna: Sosyal Bilimlerde Konumlandırılamayan Bir Düşünür Olarak Marcel Mauss
}

\author{
Şeyda Sevde Tunçbilek ${ }^{1}$ (i)
}

Öz

Fransa'da antropolojinin kurucusu Marcel Mauss (1872-1950) gerek dönemin koşulları ve sosyal ilişkilerinin getirdiği yük gerekse teorik genellemelere karşı temkinli yaklaşımı sebebiyle çok geniş bir yelpazede kaleme aldığı çalışmalarını kavramsal bir çerçeveye oturtarak genel bir kurama dönüştürmemiştir. Bu nedenle Mauss'un disiplinler arasındaki geleneksel sınırları tek hamlede geçen çalışmalarını kategorize etmek, düşünsel izleğini takip etmek, epistemolojik ve metodolojik anlamda modus operandisini sabitlemek oldukça güçtür. Mauss'un fragmanlar halinde kalan çalışmaları uzun süre Durkheim'ın sosyoloji projesinin bir tamamlayıcısı olarak görülmüş, Mauss doğal ve zorunlu bir vârislik pozisyonuna mahkûm edilmiştir. Ancak $1980^{\prime} l i$ yıllardan itibaren bu tür yaklaşımlar irtifa kaybetmiş; inançlar, ritüeller, düşünce kategorileri, semboller, bedensel teknikler ve kolektif temsiller gibi ilgi alanları ve toplumsal olguların bütünselliği, etnosentrizm eleştirisi, sosyal morfoloji incelemeleri, kültürel görecelilik savunusu gibi yönelimleri ile Mauss'un sosyal bilimler tarihinde kayda değer bir istisna olduğu düşüncesi gündeme gelmiştir. Bu çalışma, Mauss'un sosyolojik ve antropolojik yaklaşımının özgün yanlarının altını çizerek, Mauss'u Durkheim düşüncesine bitişik okumaktan vazgeçen ve orijinalliğini teslim eden akıma büyük ölçüde katılmaktadır. Ancak burada Mauss'un ikinci adam pozisyonu ile kayda değer bir istisna olma hâli arasında salınan çalışmaları Durkheim ve Mauss arasındaki insani ve mesleki yakınlıkları görmezden gelmeyen ama aynı zamanda Mauss'u Durkheim-merkezli okumalara da hapsetmeyen alternatif bir okuma biçimiyle ele alınmaktadır.

Anahtar Kelimeler: Antropoloji • Sosyoloji • Bütünsel toplumsal olgu • Armağan • Habitus • Sembolik anlam • Bedensel teknikler

The Second Man or a Remarkable Exception? Marcel Mauss as a Savant Unable to Be Positioned in the Social Sciences Abstract

Marcel Mauss (1872-1950), due to his cautious approach toward the conditions of the period and the burden social relations had brought as well as toward theoretical generalizations, never converted the articles he had published in L'Année Sociologique or the broadly dispersed articles he had written into a general theory by seating them in a conceptual framework. Therefore, categorizing Mauss' studies, which had crossed the traditional boundaries among disciplines in one thrust, following his intellectual footsteps, and stabilizing his modus operandi in the epistemological and methodological sense are quite difficult. Mauss' studies, which remain in fragments, had long been seen as a complement to Durkheim's sociology project, and Mauss had been sentenced to the position of a natural and mandatory successor. Since the 1980s, however, approaches assessing Mauss as a direct follower of Durkheim have lost altitude, and the idea that Mauss had been a remarkable exception came to the agenda through his areas of interest in such things as beliefs, rituals, categories, of thought, symbols, techniques of body, and collective representations, together with studies from social scientists like Marcel Fournier, Camille Tarot, Irène Théry, and Alain Caillé, especially in regard to Revue de M.A.U.S.S. (Mouvement anti-utilitariste dans les sciences sociales), and through orientations such as the totality of social fact, critiques on ethnocentrism, social morphology studies, and the defense of cultural relativism. By underlining the unique aspects of Mauss' sociological and anthropological approach, this study substantially contributes to the movement that has surrendered to his originality and abandoned studying Mauss adjacent to Durkheim. Though, here, Mauss' studies, oscillating between the secondary-man position and being a remarkable exception are discussed with an alternative reading that ignores not the intimacy and professional proximity between Durkheim and Mauss but also does not condemn Mauss to Durkheim-centered reading.

Keywords: Anthropology • Sociology • Total social fact $\bullet$ Gift $\bullet$ Habitus $\bullet$ Symbolic meaning $\bullet$ Techniques of body

1 Şeyda Sevde Tunçbilek (Ar. Gör.), İstanbul Üniversitesi, Edebiyat Fakültesi, Sosyoloji Bölümü, Laleli, Fatih 34134 İstanbul. Eposta: sevdetuncbilek@istanbul.edu.tr ORCID: 0000-0002-7112-5156

Atff: Tunçbilek, Ş. S. (2020). İkinci adam ya da kayda değer bir istisna: Sosyal bilimlerde konumlandırılamayan bir düşünür olarak Marcel Mauss. Istanbul Üniversitesi Sosyoloji Dergisi, 40, 499-539. https://doi.org/10.26650/SJ.2020.40.1.0008 


\section{Extended Summary}

According to some, Marcel Mauss (1872-1950) as a savant difficult to position in the tradition of the social sciences was disorganized; his studies remained superficial and he was the natural and requisite heir, a second man removed from wholeness; according to others, Mauss was a remarkable exception within 20th-century French thought who had planted the seeds of many new fields through the breadth of his areas of interest and variety of topics in his repertoire. Aside from Marcel Mauss' (1872-1950) opus magnum, the oft mentioned and referenced text Essai Sur le Don [The Gift, 1925], Mauss had not been studied until recently without being connected to Durkheim thought; in particular, the works from the last years of his life had not been evaluated, and he had stayed as a well-viewed thinker but one less seen. With his epistemological transitiveness and the variety of topics in which he was interested, marking Marcel Mauss' theoretical position and anchoring his intellectual image and heritage are nearly impossible, because as seen in his extremely short biography, "The information that remains as esoteric as the knowledge Mauss had provided is very sparse, and at the same time has left a deep impact" (Lévi-Strauss, 2013, p. 15).

Marcel Israël Mauss, born on May 10, 1872 as the eldest son of Gerson Mauss and Rosine Durkheim (Émile Durkheim's sister) in Épinal of Vosges (a region of France close to Germany), first enrolled in the Historical Sciences and Philology Chair (Section 4 of l'École Pratique des Hautes Études [EPHE]) in the fall of 1895 after completing his philosophy education in Bordeaux in the same year; afterwards he also enrolled in the History of Primitive Peoples' Religions Chair (EPHE's Section 5). There he worked on Semitic and Indo-European languages with Antoine Meillet, Lucien Finot, and Israël Lévi, and on religions with Louis Marillier, Alfred Foucher, and Sylvain Lévi. He went to England and Holland in December of 1897. There he met with the famous Indian experts Willem Calland, Moritz Winternitz, and James Frazer, who is acknowledged as one of the founders of the discipline of anthropology through his work, The Golden Bough (1890). He began giving lessons in EPHE's fifth section in 1901. In 1925, he pioneered the establishment of the Ethnology Institute (l'Institut d'Ethnologie) within the University of Paris together with Lucien Lévy-Bruhl and Paul Rivet and acted as the institute's general secretary. In 1931, this time he was elected to the Sociology Chair at the Collège de France. He resigned in 1940 when the anti-Semitic laws enforced by the Vichy Government took effect, living in retirement until February 11, 1950 when he died. According to Camille Tarot (2003, p. 8), Marcel Mauss was a frontier human in three ways: as the child in a family that alternated between tradition and modernity and tended toward modernity, as one whose family had lived on the border of Germany then settled in Épinal by choosing France after the Sedan War of 1870 and passing through the Alsace region of Bischwiller, and lastly through the epistemological transitiveness that is unable to fit within the sphere of a single discipline. 
Marcel Mauss, accepted as the founder of ethnology ${ }^{1}$ in France despite never having done any field work, aimed to identify the commonalities in various types of societies by benefitting in particular from important ethnographic monographys such as Franz Boas's The Indians of British Columbia (1888) and The Family among the Australian Aborigines (1913) and Bronislaw Malinowski's Argonauts of the Western Pacific (1922), as well as to find "one of the cornerstones upon which today's societies are built" (2013, p. 227). ${ }^{2}$ The articles Mauss had written on a broad repertoire through the psychological orientation, personal understanding, social morphology, techniques of body, magic theory, potlatch, and gifts in communities in Polynesia, Melanesia, and North America were published in fragments in L'Année sociologique, which Durkheim had founded and Marcel Mauss had been editor-inchief of since 1917. These fragments were published under the name Sociologie et Anthropologie (Sociology and Anthropology) in 1950 after his death along with Claude Lévi-Strauss's famous preface.

Marcel Mauss' first publication was the book Essai sur la nature et la fonction $d u$ sacrifice (Sacrifice: Its Nature and Functions), which he penned with Henri Hubert while in England in 1899. Immediately upon his return to France, he wrote an important article "La sociologie: Objet et méthode" ("Sociology: Object \& Method," 1901), this time with Paul Fauconnet, in which they verify the limits of the Durkheimian sociology project and advocate the necessity for sociology as a science, which was currently being established. He published his book, De quelques formes primitives de classification (Primitive Classification, 1903), which he had written with Émile Durkheim in the same year as that article. He followed this book with Esquisse d'une théorie générale de la magie (General Theory of Magic, 1904) written with Henri Hubert, "Essai sur les variations saisonnières des sociétés eskimos" ("Seasonal Variations of the Eskimo: A

1 Studies analyzing communities that were called "primitive" and that had remained outside of modern societies became an academic discipline at the start of the 20th century. While this discipline would be used in the USA with the senior title of anthropology as an uppermost heading covering physical and cultural anthropology, these studies that had been carried out on different groups of people would be included in the university system in continental Europe under the titles of "ethnography" and "ethnology." While ethnography means the detailed observation of a chosen community by the participant observer in the present time, ethnology refers to its systemization by comparing and grouping the data ethnographers have collected. However, these distinctions on the point of naming the discipline disappeared after the end of World War II, and ethnology and anthropology became synonymous apart from the nuances. This study prefers the term ethnography particularly in places where going to the field and collecting data from the field are emphasized; the designations of ethnology and anthropology are used interchangeably without any distinction in meaning.

2 Through the words of Claude Lévi-Strauss (2013, p. 38), Mauss is the first anthropologist who is considered to have been able to deduce deeper principles from ethnographic data by going beyond descriptive depictions. Perhaps the best example of this is the polemic Mauss had with Malinowski. Marcel Mauss used Malinowski's and Boas' field data in his study on exchanging patterns. In gift theory, which Mauss had formed based on these data, he criticized the definition of gratuitous donation that Malinowski had used in his Trobriand monographs. Malinowski accepted these criticisms with these words: "For a general practitioner, seeing one's observations being well presented is nice as it allows others to challenge these results with the help of their own materials" (as cited in Abélès, 2017, p. 50). While Malinowski ultimately did not possess the ethnology of his own ethnography, Mauss on the contrary was busy with an ethnology that was not his own ethnography (Tarot, 2003, p. 52). 
Study in Social Morphology" 1906) written with Beuchat, and "Introduction à l'analyse de quelques phénomènes religieux" ("Introduction to the Analysis of Some Religious Phenomena," 1908). An incomplete version of his thesis "Sur la prière" ("On Prayer") was published in 1909. In 1925, after long years of war and Durkheim's death, Mauss wrote Essai sur le don, accepted as his most important study, by starting work in order to revive the magazine L'Année sociologique. In the 1930s, he turned to studies where he portrayed the body as a micro-society, which would allow him to be accepted as the founder of body sociology in the following years, and he published the article "Les techniques du corps" ("Techniques of the Body," 1935). In this period he also wrote two articles, "Hommage à Picasso" ("Homage to Picasso," 1930) and "Arts indigène" (“Indigenous Art," 1931).

As much as the articles Mauss did write, the works he had planned to write but never started or that he had left unfinished provide an opportunity for understanding the richness of his world of thought, foremost being his study, Sur la prière, which he had left incomplete and published in 1909 in an unfinished state. The second volume of "Esquisse d'une théorie de la magie," which had been planned for addressing the relationships between magic and religion, was designed but unable to turn into a publication. He was known to be working on completing a book towards the end of the 1930s on "The macrocosmos, microcosmos, and the Tikis, human statues seen in Tahiti” (Bert, 2012, p. 18). In addition, with respect to what Fournier had transferred from Mauss' archives, Mauss had thought to transform his article "La nation" ("The Nation") into a great work in 1920; he had planned to publish a book on Bolshevism and wanted to work on technology (Fournier, 1994, pp. 15-16).

Starting in the fall of 1890 when Mauss had been a student of Durkheim in Bordeaux, a friendship developed based on professional cooperation and collaboration beyond their family relationship. After Mauss completed his high school education, Durkheim prompted him to investigate religious phenomena as a field where he would be able to use his potential and make the maximum contribution to the science of sociology from which it emerged (Mauss \& Philippe, 1979, p. 214). ${ }^{3}$ Mauss took on the task of classifying 26,000 suicide cases in 75 separate files for Durkheim's study Le suicide (Suicide, 1897; Mauss \& Philippe, 1979, p. 210). In 1903, Durkheim and Mauss coauthored the work De quelques formes primitives de classification, which addressed the relationships between social structures and classification

3 In this process, Durkheim and Mauss were convinced that the field of law and research related to institutions had already developed and that the field of ritology (Ritual Science) had advanced enough beyond a point through the studies of Sir James Frazer and Robertson Smith. They had decided on the field of oral rituals and religious conceptualization for Mauss' specialization, which they thought hadn't been attempted yet. The initial plan was for Mauss to apply the approach that Durkheim had put forth in Les règles de la méthode sociologique over religious objects. Mauss was later elected to the Chair of Comparative Religious Studies at EPHE, and he continued to deal with religious phenomena until the end of his career (Mauss \& Philippe, 1979, p. 214). 
systems and aimed to show the parallelism between societies' degrees of complexity and classification systems by comparing samples of Zunis and Chinese living in North America with Australian Aborigines. When looking at the contribution rates between 1898-1913 in the journal L'Année sociologique, which Émile Durkheim had founded and where he had brought his sociology project to life, while Durkheim ranked center at $15.9 \%$, Mauss followed him with a very high percentage of $15.2 \%$ (Tarot, 2003, p. 14). ${ }^{4}$ Regarding Les Formes élémentaires de la vie religieuse (The Elementary Forms of Religious Life, 1912), which was Durkheim's last work, Henri Hubert implied that Mauss' anthropological interests were reflected in the book, telling Mauss "Only your signature is missing," and that although it was published with a single author, the work was the product of a collective effort (Fournier, 2010, p. 474). Moreover, long before Durkheim studied Australian Aborigines in this work of his, Muass in 1889 had written a thesis on the sacrificial rites of Aborigines. After the deaths of Robert Hertz in 1915, Émile Durkheim in 1917, and Henri Hubert in 1927, Mauss became the backbone of the journal L'Année sociologique and devoted most of his work hours to preparing Durkheim's lessons and Hubert and Hertz's studies for publication. ${ }^{5}$ Marcel Mauss was by his uncle's side in difficult times such as the Dreyfus Affair and World War I up until Durkheim's death in 1917; afterward, he remained loyal to Durkheim's comparative sociology project and struggled to establish a true science of society in his studies as Durkheim's student and heir.

Perhaps for all these reasons, Mauss had for many years always been considered Durkheim's heir and complement to his projects. Nowadays, however, this type of portrait has gradually faded for Mauss; his inseminations over a very large inventory have been exposed through his areas of interest in such things as beliefs, rituals, thought categories, symbols, bodily techniques, and collective representations and his orientations such as the totality of social facts, criticism of ethnocentrism, investigations into social morphology, and defense of cultural relativism; the idea has come up that concepts such as techniques of body, formation of 'self', symbolic meaning, habitus, and communicative exchange, which are counted among the basic topics of study in today's sociology, are found in Mauss' studies in a core state, noted but not detailed.

Following the detailed and voluminous biography Marcel Fournier wrote in 1994, anecdotes and unknown aspects about Mauss one by one began to be exposed. The number of thinkers such as Robert Lowie who had assessed Mauss among social

4 Among the same years, Mauss was followed by Henri Hubert at 13\%; François Simiand at 7.8\%; Paul Fauconnet, Gaston Richard, Hubert Bourgin and Célestin Bouglé at 4.4\%, and Maurice Halbwachs at 3.9\%.

5 Henri Hubert (1872-1927), who Marcel Mauss described as his twin, was both a personal close friend and professional colleague of Mauss. While in England in 1899, Mauss wrote the article "Essai sur la nature et la fonction du sacrifice" with Hubert for the second edition of L'Année sociologique. Aside from being included within the same team of the journal, they were elected to the EPHE almost in the same year. After Hubert's death in 1927, Mauss prepared his half-finished study Mélanges de sociologie religieuse et de folklore for publication. The work was published in 1928 with an introduction from Mauss. 
scientists only as a simple follower of Durkheim gradually decreased. While LéviStrauss, Merleau-Ponty, and Lefort accepted the originality of Mauss' thinking, Dumont and Evans-Pritchard advocated in their studies that Mauss was a camouflaged critique of Durkheim (Tarot, 2003, p. 18). Since the 1990s, Mauss has again come up in various contexts as a communicative-exchange moral theorist, personality theorist, and body techniques theorist. Social scientists such as Marcel Fournier, Camille Tarot, Irène Théry, and Alain Caillé have made Mauss' studies the subject of reexamination with a different eye, particularly La Revue de M.A.U.S.S. ${ }^{6}$ While Alain Caillé claimed that Mauss in all cases deserves to be in the pantheon of great social scientists, Camille Tarot defined Mauss as "an investigative discoverer of ideas and methods; an unsystematic thinker and educator; and an innovative, anti-conformist, original, and free spirit" (2010/2, pp. 23-24). Irène Théry claims that, by separating Mauss' thinking into two stages, the first stage was when Mauss followed Durkheim's steps more; the second stage is when he focused on gender distinctions in primitive societies.

In fact, attempts to define Marcel Mauss as being akin to Durkheim but beyond him had begun at a much earlier date. Charles Andler, who had advocated Mauss for membership in Collège de France at the start of the 1930s, described Mauss as "like Durkheim but more equipped than Durkheim," while recalling Mauss as a researcher possessing ethnographic formation; as having command over many old languages such as Vedic, classical Sanskrit, Pali, and classical Hebrew from the Indo-European languages and Avestan from one of the oldest languages of $\operatorname{Iran}^{7}$ at a time when sociologists mostly had trouble with foreign languages; and as being armed with a rare dedication and passion of work. Andler stated that the Sociology Chair, which Mauss had accepted in place of the Social Philosophy Chair that had become available when Jean Izoulet died in 1929, could only be entrusted to "One of the rarest fragments of French science and philosophy" such as Mauss (Fournier, 1996, pp. 164-165).

This article assists in the effort to present Mauss, who has become increasingly visible within the social sciences, as a genuine intellectual and in abandoning studying Mauss adjacent to Durkheim's thought largely by underlining the unique aspects of Mauss sociology and anthropology. Here however develops an alternative reading that doesn't ignore the humane and professional affinities between Durkheim and Mauss and at the same time doesn't confine Mauss to a Durkheim-centered study. For

6 In addition to being a journal established in 1981 and focused on the work of Marcel Mauss, La revue de M.A.U.S.S. (Mouvement anti-utilitariste dans les sciences sociales) was a movement against the economist explanatory models that had become widespread particularly in the 1960s and 1970s and that had completely dominated the fields of sociology and political philosophy. Included among its founders are Alain Caillé, Gérald Brethoud, Cengiz Aktar, Ahmet İnsel, and Rigas Arvanitis. For more information see: Caillé, A. (2010/2). Ouverture maussienne. Revue de MAUSS, 36, pp. 25-33.

7 While addressing Marcel Mauss' sociological and anthropological approaches, one must not forget that he at the same time is a philologist. Mauss knew the languages of Latin, Greek, Arabic, and Australian, in addition to the ones mentioned in the text, and could speak English, Dutch, German, Italian, Spanish, and Russian; he lamented only being able to speak a little Swedish (König, 2014, p. 7). 
this, Mauss' interest in the observable, his multidisciplinary approach that attempts to conceptualize social fact in its entirety, his definition of individuality opposite collective consciousness, his emphasis on conflict, and his un-inherited legacy shall be discussed. The Conclusion section will present a general evaluation on the convergences and divergences between the Durkheim-Mauss duo. 


\section{I- Discussion of Method: Mauss' Practical Orientation}

Despite having remained loyal to the boundaries Durkheim drew in Les Règles de la méthode sociologique (The Rules of the Sociological Method, 1895) and putting the sociological method at the foundation of all social sciences just like Durkheim, Marcel Mauss followed a pragmatic path that transformed method from being a topic of debate into a basic tool, using this when necessary in accordance to the subject of study . He didn't discuss the issue of method at length in any study apart from the article $L a$ sociologie, which he wrote in 1901 with Michel Fouconnet and surprisingly with Durkheim's assistance (Mauss \& Philippe, 1979, pp. 241-242). According to Camille Tarot, Mauss' pluralist and eclectic approach on the topic of method and the different paths he tried in his studies stopped him from being a consistent university professor and made him a researcher in its full meaning, although less doctrinal (2003, p. 35). For this reason precisely, the first section of the work De Durkheim à Mauss l'invention du symbolique (The Invention of Symbolism from Durkheim to Mauss, 1999) is titled "Dans l'usine de Durkheim" ("In Durkheim's Factory") and the second section is titled "Dans l'atelier de Mauss" ("In Mauss' Atelier"). Likewise, François Bert published the book L'Atelier de Marcel Mauss (Marcel Mauss'Atelier, 2012).

In Mauss' thought, practice always precedes what is theoretical, because Mauss gave importance to social life, practical action, and concrete field data rather than abstract categories. He believed in the necessity of examining the world of direct social experiences with one's own eyes and in reality. Although he had never done field work throughout his life, his starter course at the university was about observing and recording social phenomena. ${ }^{1}$ Mauss inclined his students to the field in this class, explained in detail what they should do there, and made a lengthy list of the things needed in field studies. According to Robert Deliège, even Malinowski hadn't gone so far as to describe field techniques (2006, p. 97). At the same time, he worked with great curiosity by reading over and over about the materials anthropologists such as Boas and Malinowski had collected from the field. Mauss' studies are filled with countless examples and field data from a wide variety of geographies, cultures, languages, and myths. According to his student, Louis Dumont, "Mauss was a field man who never got up from his chair" (1983, p. 197).

Mauss was an empiricist who went far in abstractions and theoretical generalizations with his emphasis and excitement about actionable, concrete, and observable phenomena and social dynamics. Of his colleagues, he hailed Robert Hertz as a scholar, who conducted research projects, while criticizing Lévy-Bruhl on the point of being a philosopher. In his work Sur la prière, which he had left unfinished and published as a draft in 1909, he criticized philosophers for acting as theologians and for developing

1 This course's notes would later be made into the book, Manuel d'ethnographie (Ethnography Handbook, 1926). 
ideas about worship that they had established in their own mental worlds rather than by examining facts and practices (Mauss, 1909, p. 16). On this point, he was closer to Durkheim's methodology, which accepted each social fact as a unique reality and aimed to establish positive social science, which distinguished it from philosophy through its positivity.

Durkheim, despite accepting social fact as objects and working with concrete data in a method statistically specific to Le suicide, remained in much more of a philosophical/ theoretical position when compared with Mauss. This is because Durkheim's sociology is based on a distinction assumed to exist between traditional societies defined by mechanical solidarity and industrial societies defined by organic solidarity. He was in the search for a new morality that would be able to bring to life the ideal of a defragmented society integrated to each one of its pieces in the changing conditions together with industrialization. Whereas according to Mauss, all the possible categories and social facts need to be inventoried before constructing the categories. His doubts on the topic of premature generalizations explain to some extent the reason that he had not published any books during his career and had not formed a general theoretical framework in complete condition. ${ }^{2}$ Mauss, unlike Durkheim, was in fact not interested in theories; he maintained his beliefs in observing ethnography and research, stating the following regarding generalizations in an interview made with him in 1934:

I've never been interested in developing systematic theories in my studies. I'm just working on material that exists. If by chance I come across a generalization in these results from my studies, I state this and move on to something else. The thing I'm really interested in is not creating a general schema that will cover the whole field, but to be able to show several of the dimensions of the field whose boundaries we can touch. Because I work this way, my studies are mostly scattered and nonsystematic. Nor does any point exists that will be able to summarize them(1989, p. 165).

This distinction between Durkheim and Mauss particularly shows itself on the issue of indigenous peoples. In Mauss' seminar on the history of "primitive" peoples' religion, which he gave at EPHE in 1922, he completely broke off from the idea of doing a holistic theory of Australian totemism, which Durkheim had presented in his work Les Formes élémentaires de la vie religieuse, exhibiting an approach that rejected all types of dogmatism and that preserved the dignity of ethnographic field data which had thus far been neglected : "Mistakes disappear at every point up to the end where observations are made; Morgan and Durkheim's sacred mistake, namely that societies formed by way of external marriage, disappears into amorphous clans: Other clans emerge" (from Mauss, as cited in Bert, 2012, p. 176).

2 Another reason for Mauss' thoughts not being institutionalized is that after the death of his uncle, he dedicated most of his effort to the functioning of L'Année sociologique and preparing Durkheim's class notes for publication. Nevertheless, in his historical 1934 interview, Mauss specified falling behind due to Durkheim's studies, saying "How it is done is that the works appear more important to me than revitalizing the elderly. When I finish a study, I forget it, put it aside, and start dealing with something else." (Mauss \& Murray, 1989, p. 165). 
Although in his work De la Divison du travail social (The Division of Labor in Society, 1893) Durkheim criticized Spencer, who advocated that society can be understood through the individual, he nevertheless partnered with Spencer's approach toward passing from undefined and inconsistent homogeneity to a defined and consistent heterogeneity (Kabakc1, 2019, p. 195). For Durkheim, expressing this common denominator also meant increasingly complicating the types of societies and moving from mechanical solidarity to organic solidarity through the emergence of the individual and by detailing the division of labor. Durkheim remained true to this evolutionist line in all his studies, which also included his last study, "Les Formes élémentaires de la vie religieuse." Whereas Mauss' carefulness on the topic of ethnographic data and the field caused him to draw away from the evolutionist point of view that directly classified Durkheim's societies from basic to complex and advocated the need to also look at the most basic in order to understand the complex (Deliège, 2006, p. 98). Mauss did not believe in the existence of an evolutionary law that communities and cultures were subject to; as Franz Boas and Bronislaw Malinowski argued at the beginning of the 20th century within anthropological thought, and for Mauss as well, civilized societies and non-civilized societies did not exist, only different types of civilizations. Societies that are called "primitive" have created a unique language through their everyday life practices, beliefs, and rituals, and no criteria exists that can assume the superiority of one language over another. According to Mauss' conclusion that he drew from ethnographic data, the beliefs of so-called primitive societies are total social facts (faits social total) with a relationship to various aspects of the social system at an extraordinarily complex level that can never be addressed through a single dimension. In other words, the "simple" thing that needs to be looked at in order to understand complexity is not as "simple" as it appears from afar according to Mauss.

\section{II- Social Fact and Total Social Fact}

According to the principle of cause and effect, which Durkheim developed in his work Les Règles de la méthode sociologique, only one cause is able to influence a specific result, and when social fact are handled as objects, only one other social fact can explain these fact. Durkheim's approach in that way, where one social fact can only be explained through another social fact, is addressed from a broader perspective by Mauss because in his sociological approach, social phenomena are total social facts. Mauss advocated a social fact to mix together with the elements that form the entirety of social and physical life:

In this "total" of social facts (we suggest calling it as such), all kinds of institutions find their expression: Religious, legal, and moral institutions (moral institutions are at the same time political and family institutions) and economic institutions (which are economic institutions containing special forms related to production and consumption, more precisely to purchases and distribution); I don't suppose I even need to mention the aesthetic phenomena and the morphological phenomena from which these institutions emerge (2013, p. 226). 
For example, the gift is not a moral, economic, political, or legal necessity; it is the total social fact that encompasses and possesses regulatory function over all these. In his study "Essai sur le don," Mauss scrutinized in depth the phenomenon of exchange, which appears subject to the heading of economy, by moving it to the level of communication. He revealed the custom of the gift to be apparently voluntary yet an obligation in the background that determines and confirms social hierarchy. According to Mauss, the exchange of gifts doesn't only concern the parties of the exchange but the whole of society (2013, p. 229): "Before anything else, those who make exchanges or agreements, which falls under mutual obligation, are not individuals, they are communities...". As long as things and the spirit of those things (mana and hau) ${ }^{3}$ are exchangeable, the community develops three types of obligations on the basis of symmetrical and asymmetrical relations over the gift: giving, receiving and returning. These obligations and counter-obligations, to which Mauss gave the name "system of total prestations," are fulfilled by exchanging gifts. In this way, the gift becomes a concept that regulates all social areas. According to Mauss (2013, p. 261), the exchange of gifts "...expresses a kind of integration and intertwining. Spirits and lives mingle with one another, objects and people come out of their own worlds and integrate with each other, and this expresses the agreement and exchange with full meaning."

Just as social facts are holistic social fact (fait social total), individuals are also total human beings (l'homme total) "through their body, intuitions, emotions, wants, perceptions, and intelligence" (Mauss, 2013, p. 440) with physical-psycho-sociological sequences of actions. Mauss draws attention on this point not just to society, which expresses more than the sum of the individuals forming it, but also to the relationships and intertwining among the body, individual, and society. In the article "Les techniques $d u$ corps" in particular, he claims the way to be able to conceptualize people within their own holism is to develop a triple viewpoint on the physical, psychological, and sociological; even the intermediate form/lathe that ties together what is social with what is biological is also a psychological factor. This is because the individual's adaptation is necessary in order for what is social to be able to impact the body, namely human behavior; "Adaptation is an individual and psychological thing” (Mauss, 2001, p. 385).

In his article "Essai sur les variations saisonnières des sociétés eskimos", Mauss, like a typical Montesquieu attitude, aimed to show that the frequency of climate, social morphology, nutrition sources, population rates, social relations, family structure, ritual frequency, and religious life all affect one another holistically. In his article "Effet physique chez l'individu de l'idée de mort suggérée par la collectivité" ("The Physical Impact of the Thought of Death That Society Awakens on the Individual," 1926),

3 In Mauss anthropology, property is not just an economic term in the sense of possessing a good. Property is spiritual; the person who owns a commodity also takes over the spirit belonging to that thing. Mauss expressed this with the concept of property-talisman (Mauss, 2013, p. 239). Hau is more sylvan, mana is the ethos of people. 
where he examined cases of death in Australian and New Zealand natives by getting stuck on the idea of death that society inseminates and the acceptance of this despite the fact that they have no physical disorders or fatal injuries:

(...) these are 'total' fact that I believe need to be studied. In investigating these facts, the psychic, namely the psycho-organic, has not received sufficient attention... That which is social also needs to be taken into account. But investigating only this fragment of our lives within society is not enough by itself. (Mauss, 2001a, p. 329)

According to Claude Lévi-Strauss, Marcel Mauss's conceptualization of total social fact and also total human being is not the emphasis on originality, or holism. What is important here is that by preserving Mauss' original character of phenomena, they are different from each other but create a plurality adjacent to one another. Consequently, this totality does not harm things' originality; rather, it relates them to one another. In addition, the phenomena this holism covers are social, but what Mauss pointed out is that at the same time they are physiological and psychological. Therefore, bodies, spirits, and society are intertwined in the same moment. For example, the perpetrators, patients, materials that make doing magic possible, the spirits, and the goals during a magic ritual are within a totality (2001, p. 55). Only the concurrency of physiological, psychological, and sociological perspectives can examine this intertwining of body, spirit, and society. As such, according to Mauss and contrary to Durkheim's principle of cause and effect, social fact can be explained by evaluating social conditions and non-social conditions together.

Marcel Mauss shared Durkheim sociology's approach of accepting social fact as positive and sui generis (unique), the idea that a positive intrinsic discipline is necessary for being able to investigate these facts, and the conviction that this science can be and only be sociology. From Mauss' perspective, however, things exist within social life that cannot be directly observed, such as beliefs, values, norms, ideas, and social representations. These unobservable objects have symbolic meaning for Mauss. Mauss advocated that social fact that are to be discussed as objects cannot be investigated only as objects because social life, which is enwrapped by a mythical-ritual system, is a symbolic part of the design. From Mauss' perspective, the social extent is symbolic from start to finish:

What if words, greetings, and the gifts that are officially exchanged, received, and obligatorily returned for fear of war are each not symbols? What if the beliefs that form faith, that allow certain objects to mix together and impose the bans that cause certain objects to separate from one another, are not each symbols? (2013, pp. 426-427)

In his study Essai sur le don, gifts are not evaluated just as themselves but through the entire system of values that they symbolize and their entire meaning. Gift exchange brings together many questions on the symbolic meaning of the gift beyond its price 
and all its quantitative features, such as to whom does the gift belong, from whose spirit does the gift convey a part, how is the gift perceived by other individuals, and which gift can be equivalent to which? According to Mauss (2013, p. 426), "Sounds, words, conduct, and behavioral and moral rituals, for example, are each symbols and signs. Behaviors and moral discourses are in fact each forms of expression."

The fact that Durkheim's theoretical discourse prevents Mauss' ideas from branching out, from spreading and vaporizing, is correct; at the same time, however, the idea that expands the field that social phenomena covers in scope where Mauss' approach adds the symbolic structure of social fact to the concept of social fact and allows one to ponder the symbolic is also true. The question of symbolic meaning, which would become the particular basis of Lacan and Lévi-Strauss's approaches in the following period, had come to the center very quickly from Mauss' early studies. And even the analyses of symbolic meaning, which had not been very compatible with Durkheim's Cartesian understanding, also gradually became apparent in Durkheim's studies through Mauss' impact. In Les formes élémentaires de la vie réligieuse, Durkheim asserted that all forms, rituals, and institutions related to the sacred are symbolic forms created by people for verifying and validating collective life. According to Tarot (1999, pp. 54-55), what is new and surprising in this work is not the distinction that Durkheim made between the worldly and the sacred but religion and religiousness being addressed as a symbolically considered and designed sociality.

According to Mauss, thinking about abstract sociological theories is useless without observing social phenomena and understanding cultures, societies, and individuals using this way, because theory is necessary only as long as it allows for seeing social phenomena, for distinguishing them, and for a type of understanding which Weber called verstehende Soziologie (sociology of understanding; Mauss, 1971, p. 90). According to Dumont (1983, p. 210), Mauss' use of the verb comprendre (to understand) while referencing Weber instead of the verb savoir (to know) was a conscious and critical choice. Mauss protected Durkheim sociology from two significant threats with the emphasis he made on symbolic meaning and function. The first of these is the threat of detaching from the spirit of phenomena by making them things. Mauss eliminated the risk of objectifying by entwining bodies, spirits, and humans in the concept of total social fact and in the same way by highlighting the hau and mana things have. He again protected Durkheim sociology from automated comebacks that identify the problem and try sociological formulas that had been prepared on these questions; he deepened sociological/anthropological observation by also taking into account the indigenous point of view (Lévi-Strauss, 1960, pp. 8-10). 


\section{III- Collective Consciousness and the Concept of Self}

In Durkheim sociology, the social facts that show themselves through the external coercive force that society performs or that have the ability to perform over individuals do not source from the individual. Whether or not the individual wants, these facts impose themselves on the individual, as individuals do not cause these phenomena. The coercivity of the collective consciousness is a character that stems from the essence of social fact. Perhaps the most controversial aspect of Durkheim sociology is that it suggests a definition of individuality fully absorbed by the collective consciousness, which causes anomalies when not completely enclosed and deprives the individual of the capacity to act and make decisions. ${ }^{4}$ At no time in his career did Mauss use the concept of collective consciousness, which is a recurrent theme in Durkheim sociology (Tarot, 2003, p. 20), nor did he ever define the individual as an ersatz individu, who is controlled directly by the social consciousness. On the contrary, in many of his studies, instead of the word individu, he preferred the word agent, which derives from the verb agir (to act). ${ }^{5}$ While defining agent in his study "Les techniques $d u$ corps" (2001c, p. 371) as the intersection of physical, technical, and magical-religious actions; he described magicians as agents of magic (les agents de la magie) in the article "Esquisse d'un théorie générale de la magie" (2001b, p. 37).

The first reason Marcel Mauss didn't use Durkheim's concept of collective consciousness is that the thought of seeing all parts of society together as an integrated whole goes against Mauss' socialist engagement, which studies society through classes, human history, and class struggles. This is because Marcel Mauss was an engaged socialist, unlike Durkheim who had established his social approach on reconciliation and social morality and had carefully avoided the concepts of social class and conflict. Durkheim always kept his distance from developments in the Socialist Party, socialist editions, and class analyses, apart from his clear position on the Dreyfus Affair. Mauss, however, was directly involved in organizing a party, had met Marcel Cachin in Bordeaux where he had gone to pursue his master's in philosophy, and had joined the Socialist Student Group, which read Marx’s Das Kapital by holding regular meetings. Together with this group, Mauss invited Jean Jaurès, a leading name in France's socialist movement, to the readings in 1983. In the following years Mauss became a member in the Parti ouvrier français (French Workers' Party), took part in establishing L'Humanité (The Humanist), which was a general publication of Le Mouvement socialiste (the Socialist Movement) and the French Communist Party, among whose

4 Precisely because of these discussions, Durkheim attempted to explain the facts of the external coercion in social fact in the preface he wrote in the 1901 second edition of his work Les règles de la méthode sociologique. He stated that the process would not be able to be completely accepted as pressure and coercion because social fact can only manage individuals' behaviors provided the fact have been internalized by the individual. However, he also still insisted on the idea that social phenomena and moral rules exist independent of individuals and individuals have no involvement in this process (Kabakc1, 2019, p. 213).

5 The same choice and usage is one of the pillars of Bourdieu sociology. 
authors were also found Jean Jaurès, Karl Kautsky, Rosa Luxemburg, and Georges Sorel, and he regularly attended meetings (Bert, 2012, p. 48). Mauss wrote two articles, "L'appréciation sociologique du bolchevisme" ("Sociological Appreciation of Bolshevism") in 1924 and "La Nation" ("The Nation") in 1925.6

Durkheim sociology centers around the socialization processes that the individual will produce in society and the balanced relationship and social cohesion that will be established between the individual and society in this way. To ensure social solidarity, the required social morality needs to be adapted to modern society and the complex division of labor. Social consciousness exerts a compulsive effect on individuals as an external necessity, and at the same time enables from an early age a compromise between the individual and society through the socialization processes. The case where this compromise does not occur is an anomaly in Durkheim terminology that needs urgent intervention. According to Mauss, society is not based on solidarity (solidarité) but on the communicative exchange that enables relationships between individuals, or in other words, the principle of reciprocity (reciprocité). ${ }^{7}$ In Mauss' handling of the exchange of gifts, the potential for conflict is always present and inherent in the functioning of social dynamics. Social order is possible by different groups coming face to face and overlapping until they reach a compromise (Fournier, 1994, p. 14). The cyclical process Mauss developed in the manner of giving, receiving and returning gifts is symmetrical with the cycle of receiving, rejecting, and withholding gifts (Caillé, 2010/2, p. 31). These two cycles form the content and richness of human activities by complementing one another. Moreover, according to Lévi-Strauss, the thing called war in societies described as primitive is actually the result of a failed exchange established in reverse.

The individual, which is captured in Durkheim through the collective consciousness and is both a part of society and internalizes society, is slightly separated from the social by the 'agent' approach, which is formed in Mauss' system of total prestation through the process of taking mutual leaps forward. Mauss (2013, p. 415) defined the individual as a completely distinct source of emotion and action in the report "Rapports réels et pratiques de la psychologie et de la sociologie" that he presented on January 10, 1924 at the Société de Psychologie:

(...) when a collective vision or collective feeling completely takes over the individual's mind, or even when the activity of the individual as a whole is dedicated to a collective task, such as launching a ship, fighting, advancing, or retreating during war for example, the individual is a

6 The relationship that Marcel Mauss had established with socialism for a long time also remained almost completely in the dark after his death. Today, however, social scientists are available who have revealed the details of this relationship Mauss had and who have gathered from his archives the articles he had written in these journals. For detailed analyses regarding Marcel Mauss' political position and for detailed information beyond the scope of this article, one can look at Pierre Birnbaum's article "Marcel Mauss: Socialism and Bolshevism" (1984) and Sylvain Dzimira's work Marcel Mauss, savant et politique (2007).

7 In the next period he developed the idea where society occurs through the exchange of words, goods, and women by developing this idea of structuralism. 
completely distinct source of emotion and action. Even in such a moment, the individual's consciousness is something you need to evaluate, and we also have to consider this. Because whatever society's instinctive power is, it always leaves something sacred to the individual, namely consciousness.

Mauss attempted to explain mostly in which way and what form sociality makes an impact upon the individual, weakening Durkheim's critère de l'obligation (criteria of obligation) through the two revisions he applied on the limits of method and discipline. In his article "Esquisse d'un théorie générale de la magie," Mauss relativized this principle of obligation and asserted that all societies do not have to be compulsory. In his article "Les techniques du corps" he highlighted that community intervention cannot happen over the individual's unconsciousness by describing the interactions of the individual-body-society trio:

The intervention of consciousness on the body happens through the mediation of and thanks to society. Yet community intervention does not occur through some form of unconsciousness. Dominance is established over the consciousness, emotions, and the unconscious thanks to society, whose prepared behavioral patterns possess a specific continuity. (2001c, p. 386)

Mauss' second attempt on the topic of collective consciousness was a kind of border revision. By changing the relations between sociology with the other disciplines, Mauss included history, philology, ethnology, and psychology in his analyses. He integrated the methods of symbolic analyses and scientific analyses into sociology. This multidimensionality, as the original dimension Mauss formed for his sociology and anthropology, at the same time broadened the applicable areas and possibilities of Durkheimian sociology and actually contributed to "a generalized sociology" in this way (Tarot, 2003, p. 24). Although in this sense he had focused on many different areas and subject, Mauss' studies can be accepted as having applied Durkheim's sociology method in various fields, in a sense fully integrating Durkheim's concept of social fact, broadening it until it became total social fact. Although Mauss never mentioned the concept of collective consciousness, which is the main vein of Durkheim sociology, he also didn't hesitate to use, defend, and complete Durkheim's sociological method and eliminate its effects.

\section{IV-Academic Polytheism and the Legacy Not Inherited}

Marcel Mauss adopted academic polytheism, which since being taken as a disciplinary position had always jumped from one subject to another and touched upon everything in the face of a strict monotheism. Mauss pursued "strange pointless pleasures that had no specific goal "strange pointless pleasures that had no specific goal" (Tarot, 2003, p. 12) in a way that would often infuriate his uncle. While Durkheim had determined the limits of a discipline that had been born for the purpose of making a positive science of society and had protected it from the interventions of other 
disciplines, Mauss comfortably crossed the borders that distinguished disciplines from one another. Mauss on one hand had supported Durkheim's project for establishing sociology, but on the other hand he also stated that he would never do a militant sociology (Mauss \& Philippe, 1979, p. 211) and even pioneered the institutionalization and publication of another discipline in France, ethnology.

Mauss studied sociology together with Durkheim in parallel with his philosophy education in Bordeaux. In Paris, he was educated in philology and the comparative history of religions. He was into museology together with his close friend, Henri Hubert. He specialized in the study of Hinduism based on Sanskrit texts. When adding the occurrence of French ethnology's pater-familias to all of this, Mauss' intellectual lines appear as a kaleidoscopic image. In 1922, Mauss focused on Australian rituals and leaned toward examining Australian religions through dance figures, music, songs, and rhythm. In the 1930s, he focused on the relationship between sociology and psychology. While writing the article "Les techniques du corps" in 1935, he was busy making studies on yoga over Sanskrit texts in order to be able to uncover the biological dimension of "getting in touch with God." Mauss' studies can be evaluated as a type of intellectual ecumenism through the mobility of his mind, distribution of study topics, and breadth of his fields of interest (Tarot, 1999, p. 51). In terms of the social sciences, Mauss' "un-inherited legacy" can be said to be much more implicit, multi-directional, and dispersed, but one that is just as continuous.

The most important line that differentiates Mauss from Durkheim in the professional sense is that Mauss' anthropologic orientation and, in particular, almost all his publications after the war were in the field of ethnology. Although he was head of the Sociology Chair at the Collège de France and needed to wait for Claude Lévi-Strauss and 1959 for the Social Anthropology Chair to open up at this institution, Marcel Mauss nevertheless was the founder of anthropology in France. In 1907, he put himself forward for the presidency of the Trocérado Ethnographic Museum. For his candidacy, he wrote a text describing the state of the discipline in France and suggested ideas for reorganizing the museum. In this text he bemoaned that although ethnographic studies had become quite progressed, especially in USA, England, and Germany, it had been completely ignored in France. He stated that ethnology in France was in a very bad state both in terms of learning and research as well as collection, and that the Ethnographic Museum was also so dead that it would not attract the attention of researchers (2001d, pp. 222-226). He made quite a few suggestions such as academic institutionalization for being able to revitalize the discipline in France, increasing the number of museum staff and scholarships for those going into the field, and supporting the collection through the ministry. In 1925 together with Lévy-Bruhl and Paul Rivet, he pioneered the establishing of the Institute of Ethnology and was the leader in raising 
an anthropological generation. ${ }^{8}$ Thus he formed the French base of the discipline that had already been established under the leadership of Franz Boas in the USA and Radcliffe-Brown and Malinowski in England and enabled the discipline to be professionalized by sending young researchers into the field.

Mauss laid the foundations of structuralism through the descriptive and comparative sociology project whose purpose was to identify the associations related to the state of humanity and through the conceptualization of total social fact by showing that social expressions more precisely are always connected to systems in the background and that the systems are also interconnected. His insistence on the issue of identifying the associations in various human communities constitutes quite an efficient starting point both in terms of the structuralism of Lévi-Strauss and Louis Dumont as well as for the structural functionalist school that Radcliffe-Brown presented in British social anthropology. In France, Louis Dumont, Alfred Métraux, Georges Dumézil, Michel Leiris, and Roger Caillois can be counted among the people that Mauss directly influenced.

Mauss' core position in French anthropology and the richness of his anthropological inventory were a source of inspiration not just for Anglo-American anthropologists such as Radcliffe-Brown, Malinowski, Evans-Pritchard, Raymond Firth, Lloyd, Redfield, Eklin, and Held, but also for important thinkers like Jean Baudrillard and Jacques Derrida (Lévi-Strauss, 2013, p. 16; Eriksen \& Nielsen, 2014, p. 78). His symbolic examination of gifts allowed the thinking of symbolism that would be seen in Lacan and Lévi-Strauss; it paved the way for the idea of gift exchange and communicative exchange, as well as economic readings such as Bourdieu did or the hyperbolic readings that Derrida and in part Levinas did (Caillé, 2010/2, p. 32).

Marcel Mauss was the first person to use the concept of habitus, whose origin is based on Aristotle's concept of hexis (acquisition and ability), within the social sciences. Mauss brought the social structure of habitus to the agenda. In his article "Les techniques du corps," he defined changing habits holistically with respect to societies, socialization processes, prestige, and fashion by distinguishing the concept of habitus from

8 Among those who followed Marcel Mauss' lessons in the 1920s are very important names such as Jeanne Cuisinier, Georges Dumézil, Madeleine Francès, Marcel Griaule, Charles Haganauer, Alexandre Koyré, Raymond Lenoir, Edmond Mestre, Alfred Métraux, Georges-Henri Rivière, and André Varagnac, while in the 1930s names are found such as Roger Caillois, Germaine Dieterlen, Louis Dumont, André Georges Haudricourt, Maurice Leenhardt, Michel Leiris, André Leroi-Gourhan, Anatole Lewitzky, Déborah Lifszyc, Jean Margot-Duclot, René Maunier, Bernard Maupoil, Pierre Métais, Yvonne Oddon, Denise Paulme, Maxime Rodinson, Thérèse Rivière, André Schaeffner, Jacques Soustelle, Germaine Tillon, Jean-Pierre Vernant, and Paul-Émile Victor (from Fournier, as cited in Tarot, 2003, pp. 34-35). This means that no ethnographer will be able to be found in France who had not directly passed the lectern education of Mauss or the first generation that he had raised. 
metaphysical habits or from enigmatic memory (Mauss, 2013, p. 440). ${ }^{9}$ The concept of habitus as a socialized subjectivity and an embodied sociality, which Pierre Bourdieu developed in his Algerian monographs and his work Esquisse d'un théorie de la pratique (Bourdieu \& Wacquant, 2014, pp. 116-118) was inspired from Mauss (Fournier, 2010/2, p. 478). Likewise, Pierre Bourdieu's review of the Kabyle house and his view that tribal cosmology is shaped around the male-female dichotomy is similar to Mauss' study of social morphology where he claims that the spatial distribution of Eskimo societies and their mythical-ritual systems are differentiated over two lines: summer and winter (Tarot, 1999, pp. 32-33).

Despite leaving so much material for the social scientists to follow after him, Marcel Mauss never transformed his studies and determinations into a large general theory; even in Lévi-Strauss" words "While he unexpectedly arrived at the complete heart of the problems, he wandered from the path" (2013,p. 15). Lévi-Strauss' famous preface that he wrote in Sosyoloji ve Antropoloji, which was created by putting together the articles Marcel Mauss had published in L'Année sociologique, explained this case of deviating from the path while taking the last step as follows:

Why did Mauss halt at the edge of those immense possibilities, like Moses conducting his people all the way to a promised land whose splendor he would never behold? $\mathrm{O}$ am impelled to seek the reason, not from any wish to criticize, but out of a duty not to let the most fruitful aspect pf his thinking be lost or vitiated. Mauss might have been excepted to produce the twentieth-century social science' Novum Organum; he held all the guidelines for it, but it has only come to be revealed in fragmented form. An omission must no doubt explain this. There must be some crucial move, somewhere, that Mauss missed out (2013, p. 42).

\section{Results}

«Impossible de me dégager des travaux d'une école ${ }^{10}$

Marcel Mauss

Émile Durkheim directed Mauss' career choices and provided tactics, both as a colleague and as a relative. Mauss became his only practical heir, especially after his son André's death in 1915. In this relationship, which was complicated both academically and emotionally, Durkheim complained that Mauss was a dreamer who touched upon

9 According to Mauss, every form of behavior and bodily technique learned in the socialization process affects the muscular system and body physiology in line with the sociological conditions. One can trace Mauss' determination that the relationship sociality and humans establish with the body is intertwined and the concept of the bodily technique up to the thing that Pierre Bourdieu called "hexis corporelle." In Bachelors' Ball, an ethnographic study on villagers and marriage strategies, Bourdieu underlined physiognomy, the body, and the relationship established with the body: "Indeed, hexis corporelle is above all a social signum... He comes to perceive his body as a body marked by the social stamp, as an empaysanit, em-peasanted body, bearing the trace of the attitudes and activities associated with peasant life." (Bourdieu, 2009, pp. 91-92).

10 "It is impossible for me to turn my back on the studies of a school." 
everything through his studies, which remained at the preliminary-sketch level, but who was never clear on anything. Starting with Bordeaux, Durkheim emendated all Mauss's articles with his own hands, and constantly had suggestions not to scatter the articles or add to the article everything he found related to the topic. In fact, in 1898 Mauss was directly involved in the process of editing his work "Essai sur la nature et la fonction du sacrifice," which he wrote together with Henri Hubert, adding definitions and correcting the deviations on his own. While the interest of the young researchers focused more on what a ritual is, how it functions, its internal consistency, and its logic, Durkheim tried to draw the article over the meaning of the sacred and cult and the sanctioning power of religious phenomena. Hubert prevented this attempt by criticizing Durkheim's proposal with clear definitions and by being too philosophical. Upon this event, Mauss admonished his friend saying, "I've had enough student life for myself. I'm still living like I'm under surveillance or a truant nerd" (As cited in Bert, 2012, p. 67). In the face of Durkheim's interventions, Mauss was very much afraid of his uncle, hiding to avoid meeting him even when he was 37 years old. ${ }^{11}$

Mauss continued his commitment to the Durkheim school until the end of his life. When asked to count the founders of French sociology in an interview given in 1934, after counting Gabriel Tarde and Frédéric le Play, who had made extraordinary contributions to research and observation techniques but had been unable to carry them over to their works, as well as Lucien Lévy-Bruhl, Célestin Bouglé, and René Warms, who were Durkheim's colleagues from Bordeaux, Auguste Comte showed Émile Durkheim as the best of all these names together with stating he didn't agree with his ideas (Mauss \& Murray, 1989, p. 164). He took Durkheim's sided "against the ordinary individualism of Tarde, the shortcuts of Spencer, and the metaphysicists who defended morality and religion" (Mauss, 2013, p. 406). In the opening speech Mauss made after being selected in 1931 at the Collège de France, he hailed his father with the words, "And now just like Aeneas and Odysseus, who in order to complete their journey had to pay atonement for the souls of their missing comrades, I feel like I'm surrounded by beloved shadows. One of these is of course my mentor and second father, Durkheim, with his sturdy and thoughtful mind, his blue myopic eyes, and his passionate voice..." Afterwards he used the statement "It was up to me to take on the burden of their work," commemorating the friends he had recently lost, Henri Hubert and Robert H. Hertz (Mauss, 2012, p. 260).

He devoted much of his work after the war to the lost. He remained by his wife's side, who had suffered severe illness during the occupation. He had sequestered himself, wanting to retire because of the anti-Semitic laws that had been applied during World War II. According to the biographer Fournier (1996, p. 30), dividing Mauss' life into

11 According to a quote from his close friends Georges Davy, Davy and Mauss saw his uncle leave a building while on the terrace of a café in Sorbonne Square, and Mauss shouted, "Hurry, hide me. My uncle's coming" (Tarot, 2003, p. 8). 
two sections of the Young Mauss and the Old Mauss, as Louis Althusser had done with Marx or Steven Lukes with Durkheim, was not necessary because "Mauss being a dutiful man always remained loyal, to his family, to his friends, to his own beliefs... Young Mauss had felt older from that time, and Old Mauss was an obstinate student."

The fact that Mauss from time to time had gone other directions and formed an original intellectual line by stepping beyond Durkheim's areas of interest and methods does not mean that he surpassed Durkheim or that Durkheim had been outperformed. According to Fournier, the nephew was undoubtedly on the Durkheimian line, but he did this in his own way (1994, p. 14). According to Lévi-Strauss,

Even in his bravest steps, Mauss never thought that he had deviated from the Durkheim line. We understand this today, perhaps by doing better than Durkheim, without betraying a loyalty that was expressed so much, he showed all of us how the respectable pioneer's doctrine could be simplified and softened (1960, pp. 7-8).

As Fournier and Lévi-Strauss indicated, even if one accepts the idea that Marcel Mauss approached Durkheim sociology by revealing the theorized but unimplemented methods of Durkheim sociology and using its sociological method with the intent of classifying and interpreting the ethnographic material that had been compiled from a wide variety of geographies, one cannot ignore the fact that Mauss did sometimes deviate from the direction of Durkheim by including the world of phenomena, symbolic meaning, body as a social microcosm, conflict, communicative exchange, and reciprocity in analyses; he had developed his own approach as an original thinker and had designated many topics of study from the richness of his own thought for subsequent sociologists and anthropologists. Therefore provided that all the humane and professional relations between Mauss and Durkheim are kept in mind, one must at last give Mauss his originality and refrain from accepting him solely as Durkheim's heir and complement in conjunction with Durkheim sociology. 


\section{İkinci Adam ya da Kayda Değer Bir İstisna: Sosyal Bilimlerde Konumlandırılamayan Bir Düşünür Olarak Marcel Mauss}

Sosyal bilimler geleneğinde konumlandırılması zor bir düşünür olan Marcel Mauss (1872-1950) kimilerine göre çalışmaları yüzeysel kalmış, dağınık ve bütünlükten uzak bir ikinci adam, doğal ve zorunlu bir vâris; kimilerine göre ise yirminci yüzyıl Fransız düşüncesi içinde ilgi alanlarının genişliği ve repertuarındaki konuların çeşitliliği ile pek çok yeni alanın tohumlarını atmış kayda değer bir istisna. Opus magnumu Essai sur le don ([Armağan Üzerine Deneme] 1925) çokça anılan ve referans verilen bir metin olmakla birlikte Marcel Mauss, yakın zamana kadar Durkheim düşüncesine bitiştirilmeksizin okunmamış, özellikle yaşamının son yıllarındaki çalışmaları derinlikli değerlendirilmemiş, çok göz önünde ama az görünen bir düşünür olarak kaldı. Epistemolojik geçişkenliği ve ilgilendiği konuların çeşitliliği ile Marcel Mauss'un teorik konumunu işaretlemek, entelektüel imgesini ve mirasını sabitlemek neredeyse imkânsızdır. Çünkü son derece kısa bibliyografisinde "Mauss'un verdiği bilgiler kadar ezoterik kalan ve aynı zamanda derin bir etki bırakan pek az bilgi vardır" (Lévi-Strauss, 2013, s. 15).

10 Mayıs 1872'de Fransa'nın Almanya'ya yakın bir bölgesi olan Vosges'e bağlı Épinal'de, Gerson Mauss ile Rosine Durkheim'ın (Émile Durkheim'ın kız kardeşi) en büyük oğlu olarak dünyaya gelen Marcel Israël Mauss, 1895 yılında Bourdeux'da felsefe eğitimini tamamladıktan sonra, aynı yılın sonbaharında önce l'École pratique des hautes études (EPHE)'ün 4. Seksiyonu olan Tarihî Bilimler ve Filoloji Kürsüsüne, ardından da 5. Seksiyonu olan İlkel Halkların Dinler Tarihi Kürsüsüne kaydolur. Burada Antoine Meillet, Lucien Finot ve Israël Lévi ile semitik diller ve Hint-Avrupa dilleri üzerine; Louis Marillier, Alfred Foucher ve Sylvain Lévi ile dinler üzerine çalışır. Aralık 1897 'de İngiltere'ye ve Hollanda'ya gider. Burada ünlü Hint uzmanları Willem Calland, Moritz Winternitz ve-Golden Bough ([Altın Dal $]$ 1890) eseriyle antropoloji disiplininin kurucularından kabul edilen- James Frazer ile tanışır. 1901 yılında EPHE 5. Seksiyonda ders vermeye başlar. 1925 yılında Lucien Lévy-Bruhl ve Paul Rivet ile birlikte Paris Üniversitesi bünyesinde Etnoloji Enstitüsünün (L'Institut d'ethnologie) kurulmasına öncülük eder, Enstitünün genel sekreterliği görevini yürütür. 1931 yılında bu defa Collège de France'ta Sosyoloji Kürsüsüne seçilir. 1940 yılında Vichy Hükümeti'nin uyguladığı antisemit yasaların yürürlüğe girmesiyle istifa eder ve ölüm tarihi olan 11 Şubat 1950'ye kadar emekli hayatı yaşar. Camille Tarot'ya göre Marcel Mauss; gelenek ve modernlik arasında gidip gelen ve modernliğe meyleden bir ailenin çocuğu olması, Almanya sınırında yaşayan ailenin 1870 yılındaki Sedan Savaşı'nın ardından Fransa'yı tercih ederek Alsace Bölgesi'ndeki Bischwiller'den geçerek Épinal'e yerleşmesi ve son olarak tek bir disiplinin alanına sığdırılamayacak epistemolojik geçişkenliği ile üç şekilde bir sınır insanıdır (Tarot, 2003, s. 8). 
Fransa'da etnolojinin ${ }^{12}$ kurucusu kabul edilen Marcel Mauss, hiç alan çalışması yapmamış olmasına rağmen özellikle Franz Boas'ın The Indians of British Columbia (İngiliz Kolumbiyası Yerlileri, 1888) ve The Family among the Australian Aborigines (Avustralya Aborjinlerinde Aile, 1913) eserleri ile Bronislaw Malinowski'nin Argonauts of the Western Pacific (Bat1 Pasifik Argonotlar1, 1922)'i gibi önemli etnografik monografilerden faydalanarak farklı toplum tiplerindeki ortaklıkları tespit etmeyi ve "bugünkü toplumların üzerine kurulduğu temel taşlardan birini” bulmayı amaçlar (2013, s. 227). ${ }^{13}$ Polinezya, Melanezya ve Kuzey Amerika'daki topluluklarda armağan, insan bedeni, büyü teorisi, potlaç, bedensel teknikler, sosyal morfoloji, kişi anlayışı, psikoloji yönelimi ile çok geniş bir repertuarda yazdığı makaleler, Durkheim'ın kurduğu ve Marcel Mauss'un 1917 yılından itibaren genel yayın yönetmenliğini üstlendiği L'Année sociologique dergisinde fragmanlar hâlinde yayımlanır. Bu fragmanlar, ölümünden sonra 1950 yılında Claude Lévi-Strauss'un ünlü önsözüyle ve Sociologie et Anthropologie (Sosyoloji ve Antropoloji) adıyla kitaplaştırılır.

Marcel Mauss'un ilk yayını, 1899 yılında İngiltere' de iken Henri Hubert ile birlikte kaleme aldıkları "Essai sur la nature et la fonction du sacrifice" (Kurban Fenomeninin Doğası ve İşlevi Üzerine Deneme) başlıklı makaledir. Fransa’ya dönmesinin hemen akabinde bu defa Paul Fauconnet ile birlikte Durkheimcı sosyoloji projesinin sınırlarını doğruladıkları, henüz kurulmakta olan bir bilim olarak sosyolojinin gerekliliğini savundukları "La sociologie" (Sosyoloji, 1901) başlıklı önemli bir makale kaleme alırlar. Bu makale ile aynı yıl, Émile Durkheim ile birlikte yazdıkları De quelques formes primitives de classification (Sınıflandırmanın Bazı İlksel Biçimleri, 1903) kitabı yayımlanır. Bu kitabı Henri Hubert ile yazdıkları "Esquisse d'une théorie générale de la magie” (Genel Büyü Teorisi Üzerine Bir Deneme, 1904); Beuchat ile birlikte kaleme aldıkları "Essai sur les variations saisonnières des sociétés eskimos” (Eskimo Toplumlarındaki Mevsimsel Değişimler Üzerine Bir Deneme, 1906) ve "Introduction

12 Modern toplumların dışında kalan ve "ilkel" denilen toplulukları inceleyen çalışmalar XX. yüzyıl başında akademik disiplin haline gelir. Bu disiplin ABD'de antropoloji üst başlı̆̆ı ile fiziki ve kültürel antropolojiyi kapsayan bir üst başlık olarak kullanılırken, Kıta Avrupası'nda farklı insan topluluklarına ilişkin yürütülen bu çalışmalar "etnografi" ve "etnoloji" adıyla üniversite sistemine dahil olur. Etnografi, seçilen bir topluluğun şimdiki zamanda katılımcı gözlemci tarafindan detaylı gözlemlenmesi anlamına gelirken etnoloji, etnografların topladığı verileri karşılaştırmak ve gruplamak yoluyla sistematize edilmesini ifade eder. Ancak II. Dünya Savaşı sonrası disiplinin adlandırılması noktasındaki bu ayrımlar ortadan kalkar, etnoloji ve antropoloji -nüanslar dışında- eş anlamlı hale gelir. Bu çalışmada özellikle sahaya gitme ve sahadan veri toplama vurgusunun olduğu yerlerde etnografi terimi tercih edilmiş, etnoloji ve antropoloji adlandırmaları ise herhangi bir anlam ayrımı gözetmeksizin birbirinin yerine kullanılmıştır.

13 Claude Lévi-Strauss'un tabiriyle Mauss, betimsel tasvirin ötesine geçerek etnografik veriden daha derin gerçekliklerin çıkarsanabileceğini düşünen ilk antropologdur (2013, s. 38). Belki de bunun en iyi örneği Mauss'un Malinowski ile girdiği polemiktir. Marcel Mauss, alışveriş biçimlerine ilişkin çalışmasında Malinowski'nin ve Boas'ın saha verilerini kullanır. Bu verilerden yola çıkarak oluşturduğu armağan teorisinde ise Malinowski'nin Trobriand monografilerinde kullandığ 1 karşılıksız bağış tanımını eleştirir. Malinowski bu eleştiriyi şu sözlerle kabul eder: "Bir pratisyen için gözlemlerinin, başkalarının kendi malzemeleri yardımıyla bunların sonuçlarına itiraz etmelerine olanak sağlayacak kadar iyi sunulduğunu görmek çok hoş" (Akt. Abélès, 2017, s. 50). Nihayetinde Malinowski kendi etnografisinin etnolojisine sahip değilken, Mauss da aksine kendi etnografisi olmayan bir etnoloji ile meşguldü (Tarot, 2003, s. 52). 
à l'analyse de quelques phénomènes religieux "(Bazı Dinî Fenomenlerin İncelenmesine Giriş, 1908) incelemesi takip eder. 1909 yılında Sur la prière (İbadet Üzerine) başlıklı tezinin tamamlanmamış bir versiyonu yayımlanır. Araya giren uzun savaş yılları ve Durkheim'ın ölümünün ardından 1925 yılında Mauss, L'Année sociologique dergisini yeniden canlandırmak için işbaşı yaparak en önemli çalışması kabul edilen Essai sur le don'u kaleme alır. 1930'lu yıllarda, bedeni bir mikro-toplum olarak tasvir ettiği ve ilerleyen y1llarda beden sosyolojisinin kurucusu kabul edilmesini sağlayacak olan çalışmalara yönelir ve "Les techniques du corps " (Bedensel Teknikler, 1935) başlıklı bir makale yayımlar. Yine bu dönemde "Hommage à Picasso" (Picasso'ya Sayg1, 1930) ve "Arts indigène" (Yerli Sanatı, 1931) başlıklı iki yazı kaleme alır.

Mauss'un yazdığı makaleler kadar, yazmayı planladığı ancak çeşitli sebepler yüzünden hiç başlayamadığı ya da yarım bıraktığı eserler de onun düşün dünyasının zenginliğini anlamaya olanak verir. Bunların başında tamamlanmamış hâliyle 1909 halinde yayımladığı Sur la prière çalışması gelir. "Esquisse d'une théorie de la magie"nin büyü ve din arasındaki ilişkileri ele alması planlanan ikinci cildi de projelendirilmiş ama yayına dönüşememiştir. 1930'lu yılların sonuna doğru "Makrokozmos, mikrokozmos ve Tahiti'de görülen insan heykelleri tiki'(ti'i)ler" hakkında bir kitabı tamamlamaya çalıştığı bilinmektedir (Bert, 2012, s. 18). Ayrıca Fournier'nin Mauss'un arşivlerinden aktardığına göre Mauss 1920 yılında yayımladığı "La Nation" (Ulus) makalesini büyük bir esere dönüştürmeyi düşünmüş, Bolşevizm üzerine bir kitap yayımlamayı planlamış ve teknoloji konusunda çalı̧̧mak istemiştir (Fournier, 1994, s. 15-16).

Mauss'un Durkheim'ın Bordeaux'da öğrencisi olduğu 1890 sonbaharından itibaren aralarında akrabalık ilişkisinin ötesinde profesyonel işbirliğine ve teşriki mesaiye dayalı bir dostluk gelişti. Lisans eğitimini tamamlamasının ardından Durkheim, Mauss'u potansiyelini kullanabileceği ve doğmaktan olan sosyoloji bilimine maksimum katkıy sağlayabileceği bir alan olarak dinsel fenomenleri incelemeye yönlendirdi (Mauss ve Philippe, 1979, s. 214). ${ }^{14}$ Mauss, Durkheim'ın Le Suicide (İntihar, 1897) çalışması için 75 ayrı dosyadaki 26000 intihar vakasının sınıflandırılmasında görev aldı (1979, s. 210). Durkheim ve Mauss, 1903 yılında toplumsal yapılar ile sinıflandırma sistemleri arasındaki ilişkileri ele alan, Avustralya Aborjinlerini, Kuzey Amerika'da yaşayan Zunileri ve Çin örneklerini karşılaştırarak toplumların karmaşıklaşma dereceleri ile sinıflandırma sistemleri arasındaki paralelliği göstermeyi amaçlayan De quelques formes primitives de classification eserini birlikte kaleme aldılar. Émile Durkheim'ın kurduğu

14 Durkheim ve Mauss, bu süreçte kurumlarla ilgili araştırmaların ve hukuk alanının zaten gelişmiş, Sir James Frazer ve Robertson Smith'in çalışmalarıyla ritoloji (Rit Bilimi) alanının da bir nokta dışında yeterince ilerlemiş olduğuna kanaat getirdiler. Mauss’un uzmanlaşması için henüz el atılmadığını düşündükleri sözlü ritüeller ve dinsel kavrayış alanında karar kıldılar. Başlangıç planı Marcel Mauss'un Durkheim'ın Les règles de la méthode sociologique'de ortaya koyduğu yaklaşımın dinsel nesneler üzerinde uygulanmasıydı. Mauss, sonrasında EPHE'de Karşılaştırmalı Dinler Tarihi Kürsüsüne seçildi ve kariyerinin sonuna kadar dinsel fenomenler ile uğraşmayı sürdürdü (Mauss ve Philippe, 1979, s. 214). 
ve sosyoloji projesini hayata geçirdiği L'Année sociologique'te 1898-1913 y1lları arasında dergiye katkı oranlarında \% 15,9 ile Durkheim merkezde yer alırken Mauss \%15,2 gibi çok yüksek bir yüzdeyle onu takip etti (Tarot, 2003, s. 14). ${ }^{15}$ Durkheim'ın son eseri olan Les Formes élémentaires de la vie religieuse (Dini Hayatın İlk Biçimleri, 1912) hakkında Henri Hubert, Mauss'a "Yalnızca senin imzan eksik," diyerek Mauss'un antropolojik ilgilerinin kitaba yansıdığını, tek yazarlı yayımlanmış olmasına rağmen eserin kolektif bir çalışmanın ürünü olduğunun aşikâr olduğunu ima etti (Fournier, 2010/2, s. 474). Kald1 ki Durkheim'in bu eserde Avustralya Aborjinlerini incelemesinden çok daha önce, 1889 yılında Mauss, Aborjinlerin kurban ayinleri üzerine tez yazmaktaydı. 1915 y1lında Robert Hertz'in, 1917'de Émile Durkheim'ın ve 1927 y1lında Henri Hubert'in ölümlerinin ardından Mauss, L'Année sociologique dergisinin omurgası hâline geldi ve çalışma saatlerinin çoğunu Durkheim'ın derslerini ve Hubert ve Hertz'in çalışmalarını yayına hazırlamaya vakfetti. ${ }^{16}$

Marcel Mauss, Durkheim'ın 1917'deki ölümüne kadar Dreyfus Vakası ve I. Dünya Savaşı gibi zor zamanlarda dayısının yanındaydı, sonrasında da bir talebesi ve mirasçısı olarak çalışmalarında Durkheim'ın karşılaştırmalı sosyoloji projesine ve toplumun gerçek bir bilimini kurma çabasına sadık kaldı. Belki de tüm bu sebeplerle uzun yıllar boyunca daima Durkheim'ın vârisi ve projelerinin bir tamamlayıcısı olarak görüldü. Ancak günümüzde Mauss'un bu türlü bir portresi yavaş yavaş silikleşmekte; inançlar, ritüeller, düşünce kategorileri, semboller, bedensel teknikler ve kolektif temsiller gibi ilgi alanları ve toplumsal olguların bütünselliği, etnosentrizm eleştirisi, sosyal morfoloji incelemeleri, kültürel görecelilik savunusu gibi yönelimleri ile çok geniş bir envanterde dölleyiciliği açığa çıkmakta; çağdaş sosyolojinin temel çalışma konuları arasında sayllan beden teknikleri, benlik oluşumu, sembolik anlam, habitus ve iletişimsel mübadele gibi kavramların Mauss'un çalışmalarında nüveler halinde, işaret edilmiş ancak detaylandırılmamış halde bulunduğu fikri gündeme gelmektedir.

1994 yılında Marcel Fournier'nin yazdığ 1 detaylı ve hacimli biyografinin ardından Mauss'a dair anekdotlar ve bilinmeyen yönler peyderpey açığa çıkmaya başladı. Sosyal bilimciler arasında Mauss'u yalnızca Durkheim'ın basit bir takipçisi olarak değerlendiren Robert Lowie gibi düşünenlerin sayısı giderek azaldı. Lévi-Strauss, Merleau-Ponty ve Lefort onun düşüncesinin orijinalliğini teslim ederken, Dumont ve Evans-Pritchard Mauss'un çalışmalarında kamufle olmuş bir Durkheim eleştirisi olduğunu savundu (Tarot, 2003, s. 18). 1990'lı yıllardan itibaren Mauss; iletişimsel mübadele ahlakı

15 Aynı yıllar arasında Mauss'u \%13 ile Henri Hubert, \%7,8 ile François Simiand, \%4,4 ile Paul Fauconnet, Gaston Richard, Hubert Bourgin ve Célestin Bouglé, \%3,9 ile Maurice Halbwachs takip etti.

16 Henri Hubert (1872-1927): Marcel Mauss'un çalışma ikizi olarak tarif ettiği Hubert, Mauss'un hem kişisel anlamda yakın arkadaşı hem de mesleki anlamda çalışma arkadaşı. 1899 yılında Mauss, İngiltere'de iken L'Année sociologique'in ikinci sayısı için Hubert ile birlikte "Essai sur la nature et la fonction du sacrifice" makalesini kaleme alırlar. Dergi ekibinin içinde yer almalarının yanı sıra neredeyse aynı yıl EPHE'ye seçilirler. Mauss, Hubert'in 1927'de vefatının ardından yarım kalan Mélanges de sociologie religieuse et de folklore çalışmasını yayına hazırlar. Eser, Mauss’un girişimiyle 1928 yılında yayımlanır. 
kuramcısı, kişilik kuramcısı ve beden teknikleri kuramcısı olarak farklı bağlamlarda yeniden gündeme geldi. Başta La Revue de M.A.U.S.S. ${ }^{17}$ olmak üzere Marcel Fournier, Camille Tarot, Irène Théry ve Alain Caillé gibi sosyal bilimciler, Mauss'un çalışmalarını farklı bir gözle yeniden inceleme konusu haline getirdiler. Alain Caillé Mauss'un her halükârda büyük sosyologlar panteonunda olmayı hak ettiğini iddia ederken, Camille Tarot, onu "fikirlerin ve yöntemlerin kâşifi bir araştırmacı; sistematik olmayan bir düşünür ve eğitmen; yenilikçi, konformizm karşıtı, orijinal ve özgür bir ruh" olarak tanımladı (2010/2, s. 23-24). Irène Théry, Mauss düşüncesini iki aşamaya ayırarak, ilk döneminde daha çok Durkheim'ın izinden gittiğini, ikinci dönemde ise ilkel denilen toplumlardaki cinsiyet ayrımı üzerine yoğunlaştığını iddia etti.

Aslında Marcel Mauss'u Durkheim gibi ama onun ötesinde tanımlama girişimleri çok daha erken bir tarihte başladı. 1930'lu yılların hemen başında Mauss'un Collège de France üyeliğini savunan Charles Andler, sosyologların çoğunlukla yabancı dil sıkıntısı çektiği bir dönemde onun Hint-Avrupa dillerinden Vedik ve Klasik Sanskritçe, Pali, Klasik İbranice ve İran'ın en eski dillerinden olan Avestaca gibi pek çok eski dile hâkim, ${ }^{18}$ ender görülen bir özveri ve çalışma aşkıyla donanmış, etnografik formasyona sahip bir araştırmacı olduğunu hatırlatarak Mauss'u "Durkheim gibi ama Durkheim'dan daha donanımlı" şeklinde niteledi. 1929 yılında ölen Jean Izoulet'nin Sosyal Felsefe Kürsüsü'nün yerine açılması kabul edilen Sosyoloji Kürsüsü’nün ancak Mauss gibi "Fransız bilim ve felsefesinin en nadide fragmanlarından biri”ne emanet edilebileceğini ifade etti (Fournier, 1996, s. 164-165).

Bu makale büyük ölçüde Mauss sosyolojisinin ve antropolojisinin özgün yanlarının altını çizerek sosyal bilimler içinde giderek daha görünür hâle gelen Mauss'u Durkheim düşüncesine bitişik okumaktan vazgeçen, özgün bir entelektüel olarak tanı(t)mayı amaçlayan çalışmalara katılmaktadır. Ancak burada Durkheim ve Mauss arasındaki insani ve mesleki yakınlıkları ve geçişkenlikleri görmezden gelmeyen, ama aynı zamanda Mauss'u Durkheim-merkezli okumalara da hapsetmeyen alternatif bir okuma geliştirilmesi amaçlanmıştır. Bunun için Mauss'un Durkheim'dan farklılaştığı noktalar olarak gözlemlenebilir olana ilgisi, toplumsal olguları bütünselliği içinde kavramaya çalışan çokdisiplinli yaklaşımı, kolektif bilinç karşısındaki bireysellik tanımı, çatışma vurgusu ve vârisi olmayan mirası ele alınacaktır. Sonuç bölümünde Durkheim-Mauss ikilisi arasındaki yakınlaşmalara ve uzaklaşmalara dair genel bir değerlendirme sunulacaktır.

17 La revue de M.A.U.S.S. (Mouvement anti-utilitariste dans les sciences sociales): 1981 y1lında kurulan dergi Marcel Mauss'un çalışmalarını merkeze almakla birlikte özellikle 1960'lı ve 70'li yıllarda yaygınlaşan; sosyoloji ve politik felsefe alanını tamamen domine eden ekonomisist açıklama modellerine karşı bir hareket niteliği taşımaktadır. Derginin kurucuları arasında Alain Caillé, Gérald Brethoud, Cengiz Aktar, Ahmet İnsel ve Rigas Arvanitis yer almaktadır. Detaylı bilgi için bk. Caillé, A. (2010/2). Ouverture maussienne. Revue de MAUSS, 36, s. 25-33.

18 Marcel Mauss'un sosyolojik ve antropolojik yaklaşımını ele alırken onun aynı zamanda bir filolog olduğunu unutmamak gerekir. Mauss, metinde zikredilen dillerin yanı sıra Latince, Yunanca, Arapça ve Avustralya dillerini bilmekte, İngilizce, Felemenkçe, Almanca, İtalyanca, İspanyolca, Rusça konuşabilmekte, İsveç dilini az bildiği için hayıflanmaktadır (König, 2014, s. 7). 


\section{I- Yöntem Tartışması: Mauss'un Pratik Yönelimi}

Marcel Mauss, Durhkeim'in Les Règles de la méthode sociologique (Sosyolojik Yöntemin Kuralları, 1895)’te çizdiği sınırlara sadık kalmasına ve tıpkı Durkheim gibi bütün sosyal bilimlerin temeline sosyolojiyi koymasına rağmen yöntemi bir tartışma konusu olmaktan çıkarıp basit bir araca dönüştüren, çalışma konusuna göre ad hoc kullanan pragmatik bir yol takip eder. Michel Foucaunnet ile 1901 y1lında, Durkheim'1n yardımıla (!) (Mauss ve Philippe, 1979, s. 241-242) kaleme aldıkları La sociologie makalesi dışında hiçbir çalışmasında yöntem meselesini uzun uzadıya tartışmaz. Camille Tarot'ya göre Mauss'un yöntem konusundaki bu plüralist ve eklektik yaklaşımı, çalışmalarında denediği farklı yollar onu Durkheim gibi tutarlı bir üniversite hocası olmaktan çıkarır, daha az doktriner olmakla birlikte tam anlamıyla bir araştırmacı yapar (Tarot, 2003, s. 35). Tam da bu sebeple Mauss'u orijinal bir düşünür olarak tanımladığı De Durkheim à Mauss l'invention du symbolique (Durkheim'dan Mauss'a Sembolizmin İcad1, 1999) eserinin ilk bölümünü "Dans l'usine de Durkheim" ("Durkheim'1n Fabrikasında"), ikinci bölümünü ise "Dans 1'atelier de Mauss" ("Mauss'un Atölyesinde”) şeklinde başlıklandırır. Aynı şekilde François Bert, L'Atelier de Marcel Mauss (Marcel Mauss’un Atölyesi, 2012) başlıklı bir kitap yayımlar.

Mauss düşüncesinde pratik daima teorik olanı önceler; çünkü Mauss, soyut kategorilerden ziyade toplumsal yaşama, pratik eyleme ve somut saha verisine önem verir. Dolaysız toplumsal deneyimler dünyasını de visu ve in actu incelemenin gerekliliğine inanır. Hayatı boyunca hiç saha çalışması yapmamış olmasına rağmen üniversitede verdiği başlangıç dersi toplumsal olguları gözleme ve kaydetme üzerinedir. ${ }^{19}$ Mauss, bu derste öğrencilerini sahaya yönlendirir, sahada ne yapmaları gerektiğini detaylıca anlatır, sahada aramaları gereken şeylerin uzun uzadıya listesini yapar. Robert Deliège'e göre, Malinowski bile saha tekniklerinin betimlenmesi noktasında bu kadar ileri gitmemiştir (2006, s. 97). Aynı zamanda Boas ve Malinowski gibi antropologların sahadan topladıkları malzeme üzerinde büyük bir merakla, tekrar tekrar okumak suretiyle çalışır. Mauss'un çalışmaları çok çeşitli coğrafyalardan, kültürlerden, dillerden, mitlerden sayısız örnekle ve saha verisiyle doludur. Öğrencisi Louis Dumont'a göre "Mauss, koltuğundan hiç kalkmamış bir saha adamıdır" (1983, s. 197).

Mauss, eyleme, somut ve gözlemlenebilir olgulara ve toplumsal dinamiklere ilişkin vurgusu ve heyecanıyla soyutlamalara ve teorik genellemelere mesafe almış bir ampiristtir. Meslektaşlarından Lévy-Bruhl'ü bir filozof olması noktasında eleştirirken, araştırma projeleri yürüten Robert Hertz’i bir bilgin olarak selamlar. Yarım bıraktığ ve 1909 yılında taslak hâlinde yayımladığı Sur la prière çalışmasında, filozofları teologlar gibi davranmakla, olguları ve pratikleri incelemek yerine kendi zihin dünyalarında kurdukları ibadet fikirlerini geliştirmekle eleştirir (Mauss, 1909, s. 16). Bu noktada toplumsal olguları sui generis birer gerçeklik olarak kabul eden ve toplumun

19 Bu dersin notları sonrasında Manuel d'ethnographie (Etnografi El Kitabı, 1926) adıyla kitaplaştırılacaktır. 
pozitif-pozitif olması itibariyle felsefen ayrılan- bilimini kurmayı amaçlayan Durkheim metodolojisi ile yakınlaşır.

Ne ki toplumsal olguları şeyler olarak kabul etmesine ve somut verilerle -ki Le suicide eseri özelinde bu yöntem istatistiktir- çalışmasına rağmen Durkheim, Mauss'la karşılaştırıldığında çok daha felsefi/teorik bir konumda kalır. Çünkü Durkheim sosyolojisi mekanik dayanışmayla tanımlanan geleneksel toplum ve organik dayanışmayla tanımlanan sanayi toplumu arasında olduğu varsayılan bir ayrım üzerinde temellenir. Sanayileşme ile birlikte değişen koşullarda, bütünleşik ve parçaları birbirine entegre bir toplum idealini hayata geçirebilecek yeni bir ahlak arayışındadır. Oysa Mauss'a göre kategoriler inşa edilmeden önce mümkün olan bütün kategorilerin ve toplumsal kalemlerin envanterini çıkarmak gerekir. Prematüre genellemeler konusundaki tereddüdü onun kariyeri boyunca neden hiçbir kitap yayımlamamış olduğunu, dört başı mamur genel ve kuramsal bir çerçeve oluşturmadığını da bir ölçüde açıklar. ${ }^{20}$ Sahiden de Mauss, Durkheim'ın aksine kuramlarla ilgilenmez, etnografik gözleme ve araştırmaya inancını sürdürür, 1934 yılında kendisiyle yapılan bir röportajda genellemeler konusundaki çekincesini şu sözlerle ifade eder:

"Çalışmalarımda hiçbir zaman sistematik teoriler geliştirmekle ilgilenmedim. Sadece var olan materyal üzerinde çalışıyorum. Şayet bu çalışmalarım sonucunda bir genellemeye ulaşıyorsam bunu belirtiyorum ve başka bir şeye geçiyorum. Assl ilgilendiğim şey, bütün alanı kapsayacak genel bir şema oluşturmak değil (imkânsız bir iş!); sadece sınırlarına dokunabildiğimiz alanın boyutlarından birkaçını gösterebilmek. Bu şekilde çalıştığım için çalışmalarım çoğunlukla dağınıktır ve sistematik değildir. Onları özetleyebilecek bir nokta da yoktur”(1989, s. 165).

Durkheim ve Mauss arasındaki bu ayrışma özellikle yerli halklar konusunda kendini gösterir. Mauss 1922 yılında EPHE’de verdiği ‘ilkel' halkların dinler tarihi konulu seminerinde Durkheim'ın Les Formes élémentaires de la vie religieuse eserinde ortaya koyduğu Avustralya totemizminin bütüncül bir teorisini yapma fikrinden tamamen kopar ve o güne kadar ihmâl edilen etnografik saha verisinin onurunu kurtaran ve her türlü dogmatizmi reddeden bir yaklaşım sergiler: "Gözlemin sonuna kadar gidildiği noktada hatalar kendiliğinden ortadan kalkar, Morgan ve Durkheim'1n kutsal hatası yani toplumları dış evlilik yoluyla oluşmuş, amorf klanlara indirgeme kaybolur: Başka türlü klanlar ortaya çıkar." (Mauss’tan akt. Bert, 2012, s. 176).

Her ne kadar Durkheim De la Divison du travail social (Toplumsal İşbölümü, 1893) eserinde, toplumun bireyden hareketle anlaşllabileceğini savunan Spencer'1 eleştirse de Spencer'ın tanımsız ve tutarsız homojenlikten tanımlı ve tutarlı bir heterojenliğe geçtiği yönündeki yaklaşımıyla ortaklaşır (Kabakcı, 2019, s. 195). Durkheim'da bu

20 Mauss'un düşüncelerinin kurumlaşmamasının bir diğer nedeni de dayısının ölümünün ardından mesaisinin çoğunu L'Année sociologique' in işleyişine ve Durkheim'ın ders notlarının yayına hazırlanmasına vakfetmesidir. Yine 1934 tarihli röportajında Mauss, Durkheim’ın çalışmaları yüzünden geciktiğini belirterek "Yapılması, bana yaşlıların canlandırılmasından daha önemli görünen işler var. Bir çalışmayı bitirdiğimde onu unuturum, bir kenara koyarım ve başka bir şeyle ilgilenmeye başlarım.” (Mauss ve Murray, 1989, s. 165). 
ortak paydanın ifadesi, bireyin ortaya çıkması ve işbölümünün detaylanması ile toplum tiplerinin de giderek karmaşıklaşması ve toplumların mekanik dayanışmadan organik dayanışmaya doğru seyretmesidir. Durkheim, son çalışması olan Les Formes élémentaires de la vie religieuse de dâhil olmak üzere bütün çalışmalarında bu evrimci çizgiye sadık kalır. Oysa Mauss'un etnografik veriler ve saha konusundaki pürdikkati Durkheim'ın toplumları basitten karmaşığa doğru sınıflandıran, karmaşığı anlamak için de en basite bakmak gerektiğini savunan evrimci bakış açısından uzaklaşmasına sebep olur (Deliège, 2006, s. 98). Mauss, toplumların ve kültürlerin tabi olduğu evrimsel bir kanunun varlığına inanmaz, yirminci yüzyıl başında antropolojik düşünce içinde Franz Boas ve Bronislaw Malinowski'nin savunduğu gibi Mauss için de uygar toplumlar ve uygar-olmayan toplumlar yoktur, yalnızca farklı uygarlık tipleri vardır. 'İlkel' denilen topluluklar, gündelik hayat pratikleri, inançları, ritüelleri ile özgün bir dil meydana getirirler ve bir dilin diğerine üstünlüğünü varsayabilecek herhangi bir kıyas ölçütü tespit edilemez. Mauss'un etnografik verilerden çıkardığı sonuca göre ilkel denilen toplulukların inançları; olağanüstü karmaşık ve asla tek bir boyutla ele alınamayacak derecede toplumsal sistemin farklı veçheleriyle ilişki içinde, bütünsel toplumsal olgular (faits social total)' dır. Bir diğer deyişle Mauss'a göre karmaşı̆̆ anlamak için bakılması gereken 'basit', uzaktan göründüğ̈̈ kadar 'basit' değildir.

\section{II- Toplumsal Olgu ve Bütünsel Toplumsal Olgu}

Durkheim'in Les Règles de la méthode sociologique eserinde geliştirdiği nedensonuç (effet-cause) ilkesine göre belli bir sonuca etki eden yalnızca tek bir neden olabilir ve toplumsal olgular şeylermiş gibi ele alındığında, bu olguları ancak başka bir toplumsal olgu açıklayabilir. Durkheim'ın bir toplumsal olgunun ancak başka bir toplumsal olguyla açıklanabileceği yolundaki yaklaşımı Mauss'ta daha geniş bir perspektiften ele alınır. Çünkü Mauss'un sosyolojik yaklaşımında toplumsal olgular, bütünsel toplumsal olgulardır. Mauss, bir toplumsal olgunun sosyal ve fiziksel hayatın tamamını oluşturan unsurlar ile birbirine karıştığını savunur:

“Bu ‘toplam' sosyal olgularda (böyle denmesini öneriyoruz), her türlü kurum ifadesini bulmaktadır: Dinî, hukuki ve ahlaki kurumlar (ahlaki kurumlar aynı zamanda politik ve ailevi kurumlardır) ve ekonomik kurumlar (ki ekonomik kurumlar üretim ve tüketimle daha doğrusu alım ve dağıtımlarla ilgili özel formlar içermektedir); bu olguların vardığı estetik olguları ve bu kurumların ortaya koyduğu morfolojik olguları belirtmeye gerek bile yok sanırım” (2013, s. 226).

Örneğin armağan; moral, ekonomik, politik ya da hukuki bir gereklilik değil, tüm bunları kapsayan ve tüm bunlar üzerinde düzenleyici işleve sahip olan bütünsel toplumsal olgudur. Mauss Essai sur le don çalışmasında ekonomi başlı̆̆ına tabi görünen mübadele fenomenini iletişim düzeyine taşıyarak derinlemesine irdeler. Armağan alışverişinin görünürde gönüllü, arka planda ise toplumsal hiyerarşiyi belirleyen ve teyit eden bir zorunluluk olduğunu ifşa eder. Mauss'a göre armağan değiş-tokuşu 
yalnızca mübadelenin taraflarını değil, toplumun bütününü ilgilendirir: "Her şeyden önce, karş1lıklı yükümlülük altına giren, değiş tokuş ya da anlaşma yapanlar, bireyler değil topluluklardır..." (2013, s. 229). Şeyler ve o şeylerin ruhu (mana ve hau) ${ }^{21}$ mübadele edilebilir olduğu müddetçe topluluk, armağan üzerinden simetrik ve asimetrik ilişkiler temelinde üç tür zorunluluk geliştirir: Armağan alma, armağan verme ve armağanı iade etme. Mauss'un 'toplam yükümlülükler sistemi' adını verdiği bu yükümlülükler ve karş1-yükümlülükler armağan mübadelesi üzerinden yerine getirilirler. Böylelikle armağan toplumsalın her alanını düzenleyen bir kavram hâline gelir. Mauss'a göre armağan mübadelesi “( ...) bir tür bütünleşmeyi ve iç içe geçişi ifade etmektedir. Ruhlar ve hayatlar birbirine karışır, şeyler ve insanlar kendi dünyalarından çıkıp birbiriyle bütünleşirler ve bu, tam anlamıyla anlaşmayı ve karşılıklı değişimi ifade etmektedir.” (2013, s. 261).

Toplumsal olgular, bütünsel toplumsal olgular (fait social total) olduğu gibi birey de fiziko-psiko-sosyolojik eylem dizilerine sahip, "bedeni, sezgileri, duyguları, istemleri, algıları ve zekasıyla" (2013, s. 440) bütünsel insandır (l'homme total). Bu noktada Mauss yalnızca kendisini oluşturan bireylerin toplamından daha fazlasını ifade eden topluma değil, beden, birey ve toplum arasındaki ilişkilere ve iç içe geçmelere dikkat çeker. Özellikle "Les techniques du corps ” makalesinde insanı kendi bütünselliği içinde kavrayabilmenin yolunun fiziksel, psikolojik ve sosyolojik olmak üzere üçlü bir bakış açısı geliştirmekten geçtiğini ve hatta biyolojik olanla toplumsal olanı birbirine bağlayan ara formun/çarkın da psikolojik faktör olduğunu iddia eder. Çünkü toplumsal olanın bedene yani insan davranışına etki edebilmesi için bireyin adaptasyonu gerekir ve “Adaptasyon, bireysel ve psikolojik bir şeydir.” (Mauss, 2001, s. 385).

Mauss Eskimolar hakkındaki "Essai sur les variations saisonnières des sociétés eskimos" makalesinde Montesquieuvari bir tavırla iklimin, sosyal morfolojinin, besin kaynaklarının, nüfus oranının, toplumsal ilişkilerin, aile yapısının, ritüellerin frekansının, dinsel yaşamın hepsinin bir bütün halinde birbirine etki ettiğini göstermeyi amaçlar. Avustralya ve Yeni Zelanda yerlilerinde herhangi bir fiziksel bozukluk ya da ölümcül yara olmadığı hâlde yalnızca toplumun telkin ettiği ölüm düşüncesine saplanıp kalma ve bu kabullenme ile ölme vakalarını incelediği "Effet physique chez l'individu de l'idée de mort suggérée par la collectivité" başlıklı makalesinde bu türden ölüm vakalarının incelenebilmesi için bütünsel bir bakış açısı önerir:

“(...) bunlar üzerinde çalışılması gerektiğine inandığım "bütünsel” olgulardır. Bu olguların incelenmesinde psişik olanın, yani psiko-organiğin dikkate alınması yeterli değildir. (...) Toplumsal olanın da dikkate alınması gerekir. Ama toplum içindeki yaşamımızın yalnızca bu fragmanının incelenmesi de tek başına yeterli değildir.” (2001a, s. 329).

21 Mauss antropolojisinde mülkiyet yalnızca bir mala sahip olmak anlamında ekonomik bir terim değildir. Mülkiyet tinseldir, bir mala sahip olan kişi o şeye ait ruhu da devralır. Mauss bunu mülk-tılsım kavramı ile ifade eder (Mauss, 2013, s. 239). Hau, -daha çok ormana ait- şeylerin ruhu, mana kişilerin ruhudur. 
Claude Lévi-Strauss'a göre Marcel Mauss'un bütünsel toplumsal olgu ve bütünsel insan kavramsallaştırmasının özgün yanı bütünsellik vurgusu değildir. Burada önemli olan Mauss'un fenomenlerin özgün karakterlerini koruyarak, birbirlerinden farklı ama birbirlerine bitişik bir çokluk meydana getirmeleridir. Dolayısıyla bu bütünsellik şeylerin özgünlüklerine halel getirmez bilakis onları birbiriyle ilişkilendirir. Ayrıca bu bütünselliğin kapsadığı fenomenler sosyal olduğu kadar aynı zamanda fizyolojik ve psikolojiktir. Dolayısıyla aynı anda bedenler, ruhlar ve toplum iç içe geçer. Örneğin bir büyü ayini esnasında büyücüler/şamanlar, hastalar, büyünün yapılabilmesini mümkün kılan materyaller, ruhlar ve amaçlar bir bütünlük içindedir (2001, s. 55). Bedenin, ruhun ve toplumun bu iç içe geçişini ise ancak fizyolojik, psikolojik ve sosyolojik bakış açılarının eşzamanlılığı inceleyebilir. Öyleyse Durkheim'ın nedensonuç ilkesinin aksine Mauss'a göre toplumsal olgular ancak toplumsal olan ve toplumsal olmayan koşullar birlikte değerlendirilerek açıklanabilir.

Marcel Mauss, Durkheim sosyolojisinin toplumsal olguları pozitif ve sui generis olarak kabul etme yaklaşımını ve bu olguların incelenebilmesi için pozitif ve kendine özgü bir disiplinin gerekli olduğu fikrini, bu bilimin de ancak ve ancak sosyoloji olabileceği kanaatini paylaşır. Ancak Mauss açısından toplumsal hayatın içinde, inançlar, değerler, normlar, fikirler ve toplumsal temsiller gibi doğrudan gözlenebilir olmayan şeyler de vardır. Bu gözlemlenebilir olmayan şey Mauss'ta sembolik anlamdır. Mauss, şeylermiş gibi ele alınacak olan toplumsal olguların yalnızca şeyler olarak incelenemeyeceklerini çünkü bir mitsel-ayinsel sistem tarafından kuşatılmış toplumsal hayatın, sembolik bir tasarımın parçası olduğunu savunur. Mauss açısından toplumsal uzam baştan başa semboliktir:

"Sözcükler, selamlaşmalar, resmî bir biçimde değiş tokuş edilen, alınan ve savaş korkusuyla zorunlu iade edilen armağanlar birer sembol değilse nedir? İmanı oluşturan, bazı şeylerin birbirine karışmasını sağlayan ve bazı şeylerin birbirinden ayrılmasına neden olan yasaklamaları telkin eden inançlar birer sembol değilse nedir?” (2013, s. 426-427).

Essai sur le don çalışmasında armağanlar yalnızca kendileri olarak değil sembolize ettikleri bütün bir değerler sistemi ve anlam bütünü içinde değerlendirilir. Armağan mübadelesi; pazar değerinden ve bütün niceliksel özelliklerinden öte o armağanın kime ait olduğu, kimin ruhundan bir parça taşıdı ğı, diğer bireyler tarafından nasıl algılandığı ya da hangi armağanın hangi armağana denk olabileceği gibi armağanın sembolik anlamı üzerine pek çok soruyu beraberinde getirir. Mauss'a göre: "Sesler, sözcükler, hareketler ve örneğin davranışsal ve ahlaki ritüeller birer sembol ve işarettir. Davranışlar ve ahlâki söylevler aslında birer ifade biçimidir" (2013, s. 426).

Durkheim'ın teorik kapalılığının Mauss'un fikirlerini dallanıp budaklanmaktan, dağılıp buharlaşmaktan koruduğu doğru olduğu kadar Mauss'un toplumsal olgu kavramına toplumsal olguların sembolik yapısını ekleyen ve sembolik olanı düşünmeye 
izin veren yaklaşımının, toplumsal olgunun uzamda kapladığı alanı genişlettiği fikri de doğrudur. İlerleyen dönemde özellikle Lacan ve Lévi-Strauss'un yaklaşımlarının temeli olacak sembolik anlam sorusu, Mauss'un erken çalışmalarından itibaren çok hızıı bir şekilde merkeze gelir. Ve dahi Durkheim'ın Kartezyen anlayışıyla çok da uyumlu olmayan sembolik anlam çözümlemeleri, Mauss'un etkisiyle Durkheim'ın çalışmalarında da peyderpey görünür hale gelir. Durkheim, Les formes élémentaires de la vie réligieuse' de kutsala ilişkin bütün formların, ritüellerin ve kurumların kolektif hayatın doğrulanması ve onaylanması için insanlar tarafından yaratılmış sembolik formlar olduğunu ileri sürer. Tarot'ya göre bu eserde yeni ve çarpıcı olan Durkheim'ın dünyevi ile kutsal arasında yaptığı ayrım değil, dinin ve dinselliğin sembolik olarak düşünülmüş ve tasarlanmış bir toplumsallık olarak ele alınmasıdır (1999, s. 54-55).

Mauss'a göre toplumsal olguları gözlemlemeden ve bu yolla kültürleri, toplumları ve bireyleri anlamadan soyut sosyoloji kuramları üzerine düşünmek faydasızdır. Çünkü teori, yalnızca toplumsal olguları görmeye, tanımaya ve Weber'in verstehende Soziologie olarak adlandırdığı türden bir anlayışa izin verdiği müddetçe gereklidir (Mauss, 1971, s. 90). Dumont'a göre Mauss'un bilmek (savoir) fiili yerine Weber'i zikrederek anlamak (comprendre) fiilini kullanması bilinçli ve kritik bir tercihtir (1983 210). Lévi-Strauss'a göre Mauss, sembolik anlam ve işleve yaptığ vurgu ile Durkheim sosyolojisini iki önemli tehditten korur. Bunlardan ilki fenomenleri şeyleştirerek ruhlarından ayırma tehdididir. Mauss, bütünsel toplumsal olgu kavramında bedenleri, ruhları ve insanları iç içe geçirerek ve aynı şekilde şeylerin hausuna ve manasına dikkat çekerek cisimleşme riskini bertaraf eder. Yine aynı şekilde anlam vurgusuyla Durkheim sosyolojisini, sorunu tespit eden ve hazırda bulunan sosyolojik formülleri bu sorular üzerinden deneyen otomatikleşmiş hazırcevaplardan korur, yerli bakış açısını da hesaba katarak sosyolojik/antropolojik gözlemi derinleştirir (1960, s. 8-10).

\section{III- Kolektif Bilinç ve Benlik Oluşumu}

Durkheim sosyolojisinde, bireyler üzerinde icra ettiği ya da icra etme yeteneği taşıdığı dışsal zorlayıcı güçle kendisini gösteren toplumsal olgular bireyden kaynaklanmaz. Bu olgular bireyler tarafından meydana getirilmediği gibi birey istese de istemese de kendilerini ona empoze ederler. Kolektif bilincin zorlayıcılığı toplumsal olguların özünden kaynaklanan bir karakterdir. Durkheim sosyolojisinin belki de en tartışmalı yanı kolektif bilinç tarafından tamamen emilen, tamamen kuşatılmadığında anomaliye sebep olan bir bireysellik tanımı öne sürmesi ve bireyi eyleme ve karar verme kapasitesinden yoksun bırakmasıdır. ${ }^{22}$ Mauss kariyerinin hiçbir döneminde

22 Durkheim tam da bu tartışmalar yüzünden Les règles de la méthode sociologique eserinin 1901 yılındaki ikinci baskısına yazdığı önsözde toplumsal olguların dışsal zorlayıcılığı mevzuunu açıklamaya çalışır. Sürecin tamamen baskı ve zorlama olarak kabul edilemeyeceğini, çünkü toplumsal olguların ancak birey tarafından içselleştirilmek kaydıyla bireylerin davranışlarını yönlendirebileceğini ifade eder. Ancak yine de toplumsal olguların ve ahlaki kuralların bireylerden bağımsız şekilde var olduğu ve bireylerin bu sürece herhangi bir şekilde dâhil olmadığı fikrinde ısrar eder (Kabakcı, 2019, s. 213). 
Durkheim sosyolojisinin laytmotifi olan kolektif bilinç (conscience collective) kavramını kullanmaz (Tarot, 2003, s. 20) ve bireyi de doğrudan toplumsal bilinç tarafından yönlendirilen bir ersatz individu olarak tanımlamaz. Bilakis pek çok çalışmasında birey anlamındaki individu kelimesinin yerine agir (eylemek) fiilinden türetilen agent (fail) kelimesini tercih eder. ${ }^{23}$ "Les techniques du corps" çalışmasında faili fizik, teknik ve büyüsel-dinsel eylemlerin kesişimi olarak tanımlarken (2001c, s. 371), "Esquisse d'un théorie générale de la magie" makalesinde büyücüleri büyü ajanları (les agents de la magie) olarak tarif eder (2001b, s. 37).

Marcel Mauss'un Durkheim'ın kolektif bilinç kavramını kullanmamasının ilk sebebi, toplumu bütün parçaları birbirine entegre bir bütün olarak görme düşüncesinin Mauss'un toplumu sınıflar, insanlık tarihini de sınıf çatışmaları üzerinden okuyan sosyalist duruşuna ters düşmesidir. Çünkü Mauss, sosyolojik yaklaşımını uzlaşma ve toplumsal ahlâk üzerine kuran, toplumsal sınıf ve çatışma kavramlarından itinayla uzak duran Durkheim'ın aksine angaje bir sosyalisttir. Durkheim Dreyfus Olayı'ndaki net pozisyonu dışında, Sosyalist Parti'nin gelişimine, yayın organlarına ve sınıf analizlerine daima mesafeli kalır. Oysa Mauss, parti örgütüne doğrudan dâhil olur, felsefe lisansı yapmak üzere gittiği Bordeaux'da Marcel Cachin ile tanışır, düzenli olarak toplantılar yaparak Marx'ın Kapital'ini okuyan Sosyalist Öğrenci Grubuna katılır. Bu grupla birlikte 1893 yılında Fransa'da sosyalist hareketin önde gelen isimlerinden Jean Jaurès'yi konferansa davet eder. İlerleyen yıllarda Parti ouvrier français (Fransız İşçi Partisi)'ye üye olur ve yazarları arasında Jean Jaurès, Karl Kautsky, Rosa Luxemburg ve Georges Sorel'in de bulunduğu Le Mouvement socialiste (Sosyalist Hareket) dergisinin ve Fransız Komünist Partisi genel yayın organı olan L'Humanité (İnsanlık) gazetesinin kurulmasına katkıda bulunur, düzenli olarak toplant1larına kat1lır (Bert, 2012, s. 48). 1924'te "L'appréciation sociologique du bolchevisme” (Bolşevizmin Sosyolojik Kıymeti) ve 1925’te "La Nation” (Ulus) başlıklı iki makale kaleme alır. ${ }^{24}$

Durkheim sosyolojisi büyük ölçüde bireyi topluma mal edecek sosyalizasyon süreçlerini ve bu yolla birey ve toplum arasında kurulacak dengeli bir ilişkiyi, toplumsal bütünleşmeyi merkeze alır. Toplumsal dayanışmanın sağlanabilmesi için gerekli sosyal ahlakın, modern topluma ve karmaşıklaşan işbölümüne uyarlanması gerekir. Toplumsal bilinç dışsal bir zorunluluk olarak bireyler üzerinde zorlayıcı bir etki icra eder ve aynı zamanda erken yaşlardan itibaren sosyalizasyon süreçleri ile birey ve toplum arasında bir uzlaşma sağlanır. Bu uzlaşının oluşmaması durumu, Durkheim terminolojisinde

23 Aynı tercih ve kullanım Bourdieu sosyolojisinin de dayanaklarından biridir.

24 Marcel Mauss'un sosyalizmle kurduğu ilişsi de ölümünden sonra uzun süre neredeyse tamamen karanlıkta kalmıştır. Ancak bugün bu ilişkinin detaylarını ortaya çıkaran ve Mauss'un arşivlerinden söz konusu dergilerde yazmıș olduğu yazıları toparlayan sosyal bilimciler mevcuttur. Marcel Mauss'un politik pozisyonu ile ilgili detaylı analizler bu makalenin konusunun dışında olup detaylı bilgi için Pierre Birnbaum'un "Marcel Mauss: Socialisme et bolchévisme” (1984) makalesine ve Sylvain Dzimira'nın Marcel Mauss, savant et politique (2007) eserine bak1labilir. 
-acilen müdahale edilmesi gereken- anomalidir. Mauss’a göre toplum; dayanışma (solidarité) değil, bireyler ve topluluklar arası ilişkileri mümkün kılan iletişimsel mübadele yani karş1lıkl11ık (reciprocité) ilkesi temelinde kurulur. ${ }^{25}$ Mauss'un armağan mübadelesini ele alışında çatışma potansiyeli daima mevcuttur ve toplumsal dinamiklerin işleyişine içkindir. Toplumsal düzen ise uzlaşı kadar farklı toplumsal grupların karşı karşıya gelmeleri ve üst üste binmeleri ile mümkün olur (Fournier, 1994, s. 14). Mauss'un armağanı verme-kabul etme-geri verme şeklinde geliştirdiği döngüsel süreç, armağanı alma-reddetme-kendine saklama döngüsüyle simetriktir (Caillé, 2010/2, s. 31). Bu iki çevrim, birbirlerini tümleyerek insan eyleminin içeriğini ve zenginliğini oluşturur. Kaldı ki Lévi-Strauss'a göre ilkel denilen topluluklarda savaş diye adlandırılan şey aslında tersten kurulmuş ve başarısız olmuş bir mübadelenin sonucudur.

Durkheim'da kolektif bilinç tarafından ele geçirilen, aynı anda hem toplumun bir parçası olan hem de toplumu içselleştiren 'birey', Mauss’un karşılıklı hamle yapmak suretiyle bir toplam yükümlülükler sistemi meydana getiren 'fail' yaklaşımıyla toplumsal olandan bir nebze aralanır. Mauss, 10 Ocak 1924 tarihinde Société de Psychologie' de sunduğu "Rapports réels et pratiques de la psychologie et de la sociologie " başlıklı bildiride bireyi apayrı bir duygu ve eylem kaynağı olarak tanımlar:

“(...) kolektif bir tasavvur veya kolektif bir duygu bireyin zihnini tamamen ele geçirdiğinde ya da bireyin etkinliği bir bütün olarak, örneğin savaş sırasında bir gemiyi suya indirmek, savaşmak, ilerlemek veya geri çekilmek gibi kolektif bir çalışmaya adandığında bile, birey apayrı bir duygu ve aksiyon kaynağıdır. Böyle bir anda bile bireyin bilinci değerlendirmeniz gereken bir şeydir ve bizler de bunu göz önünde bulundurmak zorundayı. Zira toplumun telkin gücü ne olursa olsun, toplum bireye kutsal bir şey bırakır daima, yani bilincini...” (2013, s. 415)

Mauss daha çok toplumsallığın birey üzerinde hangi yolla ve ne şekilde etki ettiğini açıklamaya çalışır; Durkheim'ın dayatma ilkesini (critère de l'obligation), metotta ve disiplinin sınırlarında uyguladığı iki revizyonla seyreltir. İlk olarak "Esquisse d'un théorie générale de la magie" makalesinde bu yaptırım/zorunluluk ilkesini görecelileştirir ve bütün sosyalliklerin zorunlu olmak durumunda olmadığını ileri sürer. "Les techniques du corps ” makalesinde ise birey-beden-toplum üçlüsünün etkileşimini tarif ederken, toplumun müdahalesinin bireyin bilinçsizliği üzerinden gerçekleşemeyeceğini vurgular:

"Bilincin bedene müdahalesi toplum aracılığıyla ve sayesinde gerçekleşir. Ancak toplumun müdahalesi bir tür bilinçsizlik hâli üzerinden gerçekleşmez. Hazır davranış kalıplarının belli bir sürekliliğe sahip olduğu toplum sayesinde bilinç, duygular ve bilinçdışı üzerinde hakimiyet kurar." (2001c, s. 386).

Mauss'un kolektif bilinç konusundaki ikinci teşebbüsü bir tür sınır revizyonudur. Mauss, sosyolojisinin diğer disiplinlerle olan münasebetlerini değiştirerek tarihi,

25 Sonraki dönemde yapısalcılık bu fikri geliştirerek toplumların kelimelerin, malların ve kadınların mübadelesi ile oluştuğu fikrini geliştirir. 
filolojiyi, etnolojiyi ve psikolojiyi çözümlemelerine dahil eder. Sembolik analizleri ve dil bilimsel çözümleme yöntemlerini sosyolojiye entegre eder. Bu çok-boyutluluk Mauss sosyolojisinin ve antropolojisinin orijinal boyutunu oluşturduğu gibi aynı zamanda, Durkheimcı sosyolojinin uygulama alanını ve imkânlarını genişletir ve asıl böylelikle "genelleştirilmiş bir sosyoloji" projesine katkı sağlar (Tarot, 2003, s. 24). $\mathrm{Bu}$ anlamda çok farklı alanlara ve konulara yönelmekle birlikte Mauss'un çalışmaları; Durkheim'ın sosyoloji yönteminin farklı alanlarda uygulanması, bir anlamda Durkheim'ın toplumsal olgu kavramının bütünselleştirilmesi, bütünsel toplumsal olgu olana dek genişletilmesi olarak kabul edilebilir. Mauss, Durkheim sosyolojisinin ana damarı olan kolektif bilinç kavramını hiçbir çalışmasında zikretmemekle birlikte Durkheim'in sosyolojik yöntemini kullanmaktan, savunmaktan, tamamlamaktan ve istenmeyen/öngörülemeyen etkileri bertaraf etmekten de geri durmaz.

\section{IV-Akademik Çoktanrıcılık ve Vârisi Olmayan Miras}

Marcel Mauss, disipliner pozisyon alış itibariyle katı bir tektanrıcılığın karşısında daima daldan dala konan ve her şeye dokunan çoktanrıcılı̆̆ benimser. Çoğunlukla dayısını çileden çıkaracak şekilde "amaçsız ve belirli bir hedefi olmayan garip zevklerinin" (Tarot, 2003, s. 12) peşinden gider. Durkheim, toplumun pozitif bir bilimini yapma amacıyla doğmakta olan bir disiplinin sınırlarını belirlerken ve onu diğer disiplinlerin müdahalelerinden korurken, Mauss disiplinleri birbirinden ayıran sınırları rahatça geçer. Mauss, bir yandan Durkheim'ın sosyolojiyi kurma projesine destek verir, öte yandan da hiçbir zaman militan bir sosyoloji yapmadığını dile getirir (Mauss ve Philippe, 1979, s. 211) ve hatta Fransa'da bir başka disiplinin, etnolojinin kurumsallaşmasına ve yaygınlaşmasına öncülük eder.

Mauss Bordeaux'daki felsefe eğitimine koşut olarak Durkheim ile birlikte sosyoloji çalışır. Paris'te filoloji ve karşılaştırmalı dinler tarihi eğitimi alır. Yakın arkadaşı Henri Hubert ile birlikte müzeolojiye merak salar. Sanskritçe metinlerden hareketle Hindoloji alanında uzmanlaşır. Tüm bunların üzerine Fransız etnolojisinin pater-familiası oluşu da eklendiğinde Mauss'un entelektüel çizgisi kaleydoskopik bir görüntü olarak belirir. Mauss 1922 yılında Avustralya ritüelleri üzerine yoğunlaşır ve dans figürleri, müzik, şark1, ritim üzerinden Avustralya dinlerini incelemeye yönelir. 1930'lu yıllarda sosyoloji ve psikoloji arasındaki ilişkilere odaklanır. 1935 yılında "Les techniques du corps" makalesini yazarken 'Tanrıyla iletişime geçmenin' biyolojik boyutunu açığa çıkarabilmek için Sanskritçe metinler üzerinden yoga ile ilgili çalışmalar yapmakla meşguldür. Zihninin hareketliliği, çalışma konularının dağılımı ve ilgi alanlarının genişliği ile Mauss'un çalışmaları bir tür entelektüel ekümenizm olarak değerlendirilebilir (Tarot, 1999, s. 51). Sosyal bilimler açısından Mauss'un "vârisi olmayan mirası"nın çok daha örtük, çok yönlü, dağınık ama bir o kadar da sürekli olduğundan söz edilebilir. 
Mauss'u mesleki anlamda Durkheim'dan farklı kılan en önemli çizgi, Mauss'un antropoloji yönelimi ve özellikle savaş sonrası yayınlarının neredeyse tamamının etnoloji alanında olmasıdır. Her ne kadar Collège de France'ta Sosyoloji Kürsüsünün başına geçse de ve bu kurumda açılacak bir Sosyal Antropoloji Kürsüsü için Claude Lévi-Strauss'u ve 1959 yılını beklemek gerekecekse de Fransa'da antropolojinin kurucusu Marcel Mauss'tur. 1907 yılında Trocérado Etnografi Müzesinin başkanlığına adaylığını koyar. Adaylığı için Fransa'da disiplinin durumunu açıklayan ve müzenin yeniden organize edilmesine ilişkin fikirler öne süren bir metin kaleme alır. Bu metinde özellikle ABD, İngiltere ve Almanya'da etnografik çalışmaların oldukça ilerlemiş olmasına rağmen Fransa' da göz ardı edildiğinden yakınır. Fransa'da etnolojinin gerek öğrenim gerek araştırma gerekse koleksiyon bakımından çok kötü durumda olduğunu ve Etnografi Müzesinin de araştırmacıların ilgisini çekmeyecek denli ölü olduğunu ifade eder (2001d, s. 222-226). Disiplinin Fransa'da canlandırılabilmesi için akademik kurumsallaşma, müzenin personel sayısını ve sahaya gidecekler için bursların arttırılması, koleksiyonların bakanlıkça desteklenmesi gibi pek çok öneride bulunur. 1925 yılında Lévy-Bruhl ve Paul Rivet ile birlikte Etnoloji Enstitüsünün kurulmasına öncülük eder ve akademik kariyeri boyunca bir antropolog kuşağının yetişmesine önayak olur ${ }^{26}$. Böylelikle ABD'de Franz Boas'ın ve İngiltere'de Radcliffe-Brown ve Malinowski'nin öncülüğünde zaten kurulmuş olan disiplinin Fransa ayağını oluşturur ve genç araştırmacıları sahaya göndererek disiplinin profesyonelleşmesini sağlar.

Mauss, amacı insanlık durumuna ilişkin ortaklıkları tespit etmek olan betimsel ve karşılaştırmalı sosyoloji projesiyle ve bütünsel toplumsal olgu kavramsallaştırmasıyla, daha doğrusu toplumsal dışavurumların arka planda daima sistemlere bağlı olduğunu, sistemlerin de birbirine bağlı olduğunu göstererek yapısalcılığın temelini atar. Çeşitli insan topluluklarındaki ortaklıkların tespiti konusundaki ısrarı, hem Lévi-Strauss ve Louis Dumont yapısalcılığı açısından hem de İngiliz sosyal antropolojisinde RadcliffeBrown'ın temsil ettiği yapısal işlevselci ekol için oldukça verimli bir başlangıç noktasını teşkil eder. Fransa'da Mauss'un doğrudan etkilediği kişiler arasında Louis Dumont, Alfred Métraux, Georges Dumézil, Michel Leiris ve Roger Caillois sayılabilir.

Mauss'un Fransız antropolojisindeki çekirdek konumu ve antropolojik envanterinin zenginliği yalnızca Radcliffe-Brown, Malinowski, Evans-Pritchard, Raymond Firth, Lloyd, Redfield, Eklin, Held gibi Anglo-Amerikan antropologlar için değil, Jean

26 1920'lerde Marcel Mauss'un derslerini takip edenler arasında Jeanne Cuisinier, Georges Dumézil, Madeleine Francès, Marcel Griaule, Charles Haganauer, Alexandre Koyré, Raymond Lenoir, Edmond Mestre, Alfred Métraux, Georges-Henri Rivière, André Varagnac gibi çok önemli isimler bulunurken, 1930'lu yıllarda Roger Caillois, Germaine Dieterlen, Louis Dumont, André Georges Haudricourt, Maurice Leenhardt, Michel Leiris, André Leroi-Gourhan, Anatole Lewitzky, Déborah Lifszyc, Jean Margot-Duclot, RenéMaunier, Bernard Maupoil, Pierre Métais, Yvonne Oddon, Denise Paulme, Maxime Rodinson, Thérèse Rivière, André Schaeffner, Jacques Soustelle, Germaine Tillon, Jean-Pierre Vernant, Paul-Émile Victor gibi isimler bulunmaktadır (Fournier'den akt. Tarot, 2003, s. 34-35). Bunun anlamı, Fransa'da doğrudan Mauss'un ya da onun yetiştirdiği ilk kuşağın rahle-i tedrisinden geçmemiş etnografin bulunamayacağıdır. 
Baudrillard, Jacques Derrida gibi önemli düşünürler için de esin kaynağ1 olur (LéviStrauss, 2013, s. 16; Eriksen ve Nielsen, 2014, s. 78). Armağanın sembolik incelenmesi, Lacan ve Lévi-Strauss'ta görülecek sembolizmi düşünmeye izin verir; armağan mübadelesi ve iletişimsel mübadele fikri, Bourdieu'nün yaptığı gibi ekonomik ya da Derrida'nın ve kısmen Levinas'ın yaptığı gibi hiperbolik okumaların yolunu açar (Caillé, 2010/2, s. 32).

Köken itibariyle Aristoteles'in hexis (edinme ve yetenek) kavramına dayanan habitus kavramını sosyal bilimler içinde kullanan ilk kişi Marcel Mauss’tur. "Les techniques du corps ” makalesinde habitusun toplumsallığını vurgular; ve kavramı metafizik alışkanlıklardan ya da gizemli hafızadan ayırarak toplumlara, sosyalleşme süreçlerine, prestije ve modaya göre değişen alışkanlıklar bütünü olarak tanımlar (Mauss, 2013, s. 440). ${ }^{27}$ Pierre Bourdieu'nün Cezayir monografileri ve Esquisse d'un théorie de la pratique eserinde geliştirdiği, toplumsallaşmış bir öznellik ve bedenlenmiş bir toplumsallık olarak habitus kavramı Mauss'tan mülhemdir (Bourdieu ve Wacquant, 2014, s. 116-118 ; Fournier, 2010/2, s. 478). Aynı şekilde Pierre Bourdieu'nün Kabiliye evi hakkındaki incelemesi ve Kabiliye kozmolojisinin kadın-erkek dikotomisi etrafında şekillendiği görüşü, Mauss'un Eskimo topluluklarının mekânda dağılımlarının, mitselayinsel sistemlerinin yaz ve kış olmak üzere iki hat üzerinde farklılaştığını iddia ettiği sosyal morfoloji çalışmasının bir benzeridir (Tarot, 1999, s. 32-33).

Kendisinden sonraki sosyal bilimciler için bunca malzeme bırakmış olmasına rağmen Marcel Mauss hiçbir zaman çalışmalarını ve tespitlerini genel büyük bir kurama dönüştürmez hatta "beklenmedik bir şekilde sorunların tam kalbine ulaşacakken yolundan sap[ar]" (2013, s. 15). Lévi-Strauss, son adımı atacakken yoldan sapma hâlini, Marcel Mauss'un L'Année sociologique'te yayımlanan makalelerinin bir araya getirilmesiyle oluşturulan Sosyoloji ve Antropoloji eserine yazdığı ünlü önsözde şöyle açıklar:

“(...) bizler, eleştirel bir anlayış içerisinde değil de daha ziyade Mauss’un öğrettiği şeylerin en önemli kısmını gözden kaybetmeme ya da içeriğini bozmama düşüncesiyle, Mauss’un tıpkı halkını vaat edilen topraklara götüren ama o toprakların ihtişamını görme olanağına hiçbir zaman kavuşamayan Musa Peygamber gibi bu sonsuz olanaklara ulaşıp da neden daha ileriye gitmediğini araştırmaya çalışıyoruz. Bir yerlerde Mauss'un aşamadığı bir şey, bir geçit olması lâzım ki Mauss'un aşamadığı bu geçit, kendisinden bekleyebileceğimiz ve bütün iplerini elinde tuttuğu 20. yüzyılın Novum Organumu'nun neden sadece fragmanlar düzeyinde kaldığını açıklayabilir kesinlikle" (2013, s. 42).

27 Mauss'a göre sosyalleşme süreçlerinde öğrenilen her davranış biçimi ve bedensel teknikler sosyolojik koşullar doğrultusunda kas sistemini ve vücut fizyolojisini etkiler. Mauss'un toplumsallık ve insanın bedeniyle kurduğu ilişkinin iç içe geçtiği tespitini ve bedensel teknikler kavramının izini Pierre Bourdieu'nün 'hexis corporelle’ dediği şeye kadar sürmek mümkündür. Bourdieu, köylüler ve evlenme stratejileri üzerine etnografik bir çalışma olan Bekârlar Balosu'nda fizyonominin, bedenin ve bedenle kurulan ilişkinin altını çizer: “Gerçekten de bedensel hexis her şeyden önce bir toplumsal signum'dur. (...) Bedenini, toplumsal izin damgasını vurduğu, köy yaşamına bağlı davranışların ve işlerin izlerini taşıyan empeysanit, köylü bir beden olarak görecektir.” (Bourdieu, 2009, s. 91-92). 


\section{Sonuç}

«Impossible de me dégager des travaux d'une école $»^{28}$

Marcel Mauss

Émile Durkheim hem bir meslektaşı hem de akrabası olarak Mauss'un kariyer tercihlerini yönlendirdi, taktikler verdi. Mauss, özellikle de oğlu André'nin 1915'teki ölümünün ardından, Durkheim'ın neredeyse tek mirasçısı durumuna geldi. Hem akademik hem de duygusal anlamda çetrefilli olan bu ilişkide Durkheim, Mauss'un eskiz düzeyinde kalan çalışmalarıyla her şeye dokunan ama hiçbir şeyde netleşmeyen bir hayalperest olmasından şikayetçiydi. Bordeaux'dan itibaren Mauss'un bütün yazılarını kendi eliyle düzeltti, dağılmaması ve konuyla ilgili bulduğu her şeyi yazıya eklememesi yönünde sürekli telkinlerde bulundu. Hatta 1898 yılında Mauss ve Henri Hubert' in birlikte kaleme aldıkları "Essai sur la nature et la fonction du sacrifice" çalışmasının redaksiyon sürecine doğrudan müdahil oldu, tanımlar ekledi, sapmaları -kendince- düzenledi. Genç araştırmacıların ilgisi daha çok bir ritüelin ne olduğu, nasıl işlediği, iç tutarlılığı ve mantığ üzerinde yoğunlaşmışken Durkheim yazıyı kutsalın ve kültün anlamı ve dinî fenomenlerin yaptırım gücü üzerine çekmeye çalıştı. Hubert, Durkheim'ın teklifini net tanımlar içermekle ve fazla felsefi olmakla eleştirerek bu teşebbüsün önüne geçti. Bu olay üzerine Mauss, arkadaşına "Kendi adıma yeterince öğrencilik hayatı yaşadım. Gözetim altında ya da okul kaçağı inek bir öğrenci gibi hâlâ da yaşıyorum.” diye sitem etti (Akt. Bert, 2012, s. 67). Durkheim'ın müdahaleleri karşısında Mauss, 37 yaşına geldiğinde dahi onunla karşılaşmamak için saklanacak denli dayısından çekinir durumdaydı. ${ }^{29}$

Mauss, Durkheim ekolüne bağlılığını yaşamının sonuna kadar sürdürdü. 1934 yılında verdiği röportajda Fransız sosyolojisinin kurucularını sayması istendiğinde; Auguste Comte, fikirlerine katılmadığını belirtmekle birlikte Gabriel Tarde, araştırma ve gözlem teknikleri konusunda olağanüstü katkıları olan ama bunu eserlerine taşıyamayan Frédéric le Play, Durkheim'ın Bordeaux'dan meslektaşı Lucien Lévy-Bruhl, Célestin Bouglé ve René Warms'u saydiktan sonra bu isimlerin hepsinden daha iyisi olarak Durkheim'1 gösterdi (Mauss ve Murray, 1989, s. 164). “Tarde'ın sıradan bireyciliğine, Spencer'ın kolaycılığına, ahlâkı ve dini savunan metafizikçilere karşı” Durkheim'ın tarafını tuttu (Mauss, 2013, s. 406). 1931 yılında Collège de France'a seçilmesinin ardından yaptığ açı1ış konuşmasında dayısını "Ve şimdi, tıpkı yolculuklarını tamamlayabilmek için kefaretlerini kayıp yoldaşlarının ruhuna ödemek zorunda kalan Aineais ve Odisseais gibi kendimi burada sevgili gölgelerimizle çevriliymiş gibi hissediyorum. Bunlardan biri elbette üstadım ve ikinci babam Durkheim; sağlam ve düşünceli kafası, mavi miyop gözleri ve tutkulu sesiyle..." sözleriyle selamladı. Ardından da kısa zaman önce kaybettiği

28 "Bir ekolün çalışmalarına sırt çevirmek benim için imkânsız."

29 Yakın arkadaşı Georges Davy’nin aktardığına göre, Davy ve Mauss, Sorbonne Meydanı'nda bir kafenin terasındalarken, Mauss (yaklaşık 37 yaşında), dayısının bir binadan çıktığını görür ve "Acele et, beni sakla. Dayım geliyor!" diye bağırır (Tarot, 2003, s. 8). 
dostları Henri Hubert ve Robert H. Hertz'i anarak “Onların çalışmalarının yükünü sırtlanmak bana düştü” ifadelerini kullandı (Mauss, 2012, s. 260).

Savaş sonrası mesaisinin büyük kısmını kayıplara adadı. İşgal dönemi boyunca, ağır bir hastalık geçiren karısının yanında kaldı. İkinci Dünya Savaşı sırasında uygulanan antisemit yasalar yüzünden emekliliğini isteyerek köşesine çekildi. Biyografi Fournier'ye göre Mauss'un hayatını, Louis Althusser'in Marx'a ya da Steven Lukes'in Durkheim'a yaptığı gibi Genç Mauss ve Yaşlı Mauss olarak ikiye bölmenin lüzumu yoktur; çünkü: "Bir görev adamı olarak Mauss daima sadık kaldı; ailesine, arkadaşlarına ve kendi inançlarına... Genç Mauss, kendini daha o zamandan yaşlı hissediyordu; Yaşl1 Mauss ise müzmin bir öğrenciydi.” (1996, s. 30).

Mauss'un zaman zaman Durkheim'ın ilgi alanlarının ve metotlarının dışına çıkarak başka yönlere gitmiş olması, özgün entelektüel bir çizgi oluşturması Durkheim'1 aştı̆̆ 1 ya da Durkheim'ın aşıldığı anlamına gelmez. Fournier'ye göre yeğen şüphesiz Durkheimc1 çizgideydi ama bunu kendi tarzında yaptı (1994, s. 14). Lévi-Strauss'a göre ise, "Mauss, en cesur adımlarında bile hiçbir zaman Durkheim çizgisinden saptığını düşünmedi. Belki de ondan daha iyisini yaparak, bunu bugün anlıyoruz, bunca dile getirilen bir sadakate ihanet etmeksizin, muteber öncüsünün doktrininin nasıl sadeleştirilebileceğini ve yumuşatılabileceğini hepimize gösterdi.” (1960, s. 7-8).

Fournier ve Lévi-Strauss'un belirttiği gibi Marcel Mauss'un, Durkheim sosyolojisinin teorize edilmiş fakat uygulamaya konulmamış yönlerini açığa çıkararak ve sosyolojik yöntemini çok çeşitli coğrafyalardan derlenmiş etnografik malzemenin tasnifi ve yorumlanması amacıyla kullanarak Durkheim sosyolojisine yaklaştığı düşüncesi kabul edilse bile; görüngüler dünyasını, sembolik anlamı, toplumsal bir mikrokozmos olarak bedeni, çatışmayı, iletişimsel mübadeleyi, karşılıklılı̆̆ ve çokdisiplinliliği analize dahil ederek zaman zaman Durkheim istikametinden saptığı, orijinal bir düşünür olarak kendi yaklaşımını geliştirdiği ve düşüncesinin zenginliği ile kendisinden sonraki sosyologlar ve antropologlar açısından pek çok çalışma konusuna işaret ettiği göz ardı edilemez. Dolayısıyla Mauss ve Durkheim arasındaki tüm insani ve mesleki münasebetler akılda tutulmak kaydıyla son kertede Mauss'u yalnızca Durkheim sosyolojisine bitişik, onun mirasçısı ve tamamlayıcısı olarak kabul etmekten sakınmak ve Mauss'un hakkını Mauss'a teslim etmek gerekir.

Hakem Değerlendirmesi: Dış bağımsız.

Çıkar Çatışması: Yazar çıkar çatışması bildirmemiştir.

Finansal Destek: Yazar bu çalışma için finansal destek almadığını beyan etmiştir.

Peer-review: Externally peer-reviewed.

Conflict of Interest: The author declares no potential conflicts of interest with respect to the research, authorship, and/or publication of this article.

Grant Support: The author received no financial support for the research, authorship, and/or publication of this article. 


\section{Kaynakça/References}

Abélès, M. (2017). Devletin Antropolojisi (2. basım, N. Ökten, Çev.). Dipnot Yayınları.

Bert, J.-F. (2012). L'Atelier de Marcel Mauss-Un anthropologue paradoxal. CNRS Éditions.

Bert, J.-F. (2012). Par quoi se définit une religion « élémentaire» ? Notes sur le séminaire de Marcel Mauss à l'EPHE (1922-1923). Archives de Sciences Sociales des Religions, 159, 171-201.

Birnbaum, P. (1984). Marcel Mauss: Socialisme et bolchévisme. Dans: P. Birnbaum, Dimensions du pouvoir (pp. 55-60). Presses Universitaires de France.

Bourdieu, P. (2009). Bekârlar Balosu (Ç. Eroğlu, Çev.). Dost Kitabevi Yayınları.

Bourdieu, P., \& Wacquant, L. (2014). Düşünümsel Bir Antropoloji İçin Cevaplar (7. basım, N. Ökten, Çev.) İletişim Yayınları.

Caillé, A. (2010/2). Ouverture maussienne. Revue de MAUSS, 36, 25-33.

Chanial, P. (2010/2). Bourdieu, un « héritier » paradoxal? Reveu du MAUSS, 36, 483-492.

Deliège, R. (2006). Une histoire d'anthropologie. Éditions du Seuil.

Dumont, L. (1983). Marcel Mauss: une science en devenir. Dans Essais sur l'individualisme: Une perspective anthropologique sur l'idéologie moderne (pp. 193-215). Éditions du Seuil.

Dzimira, S. (2007). Marcel Mauss, savant et politique. Édition La Découverte/M.A.U.S.S.

Eriksen, T. H., \& Nielsen, F. S. (2014). Antropoloji tarihi (4. basım, A. Bora, çev.). İletişim Yayınları.

Fournier, M. (1994). Marcel Mauss. Fayard.

Fournier, M. (1996). L'élection de Marcel Mauss au Collège de France. Genèses. Sciences sociales et histoire, 22(1), 160-165.

Fournier, M. (1996). Si je devais réécrire la biographie de Marcel Mauss... Revue européenne des sciences sociales, 34(105), 27-37.

Fournier, M. (2010/2). Durkheim, Mauss et Bourdieu: Une filiation? Revue de MAUSS, 473-482.

König, R. (2014). Marcel Mauss (1872-1950). Trivium [En ligne].

Kabakc1, E. (2019). Sosyolojiyi kurmak. Vadi Yayınları.

Lévi-Strauss. (2013). Marcel Mauss'un Eserine Giriş. Sosyoloji ve Antropoloji içinde (Ö. Doğan, Çev., s. 15-57). Doğu Batı Yayınları.

Lévi-Strauss, C. (1960). Leçon inaugurale faite le Mardi 5 Janvier 1960. Chaire d'Anthropologie Sociale, Collège de France.

Mauss, M. (1971). Essais de sociologie. Éditions de Minuit.

Mauss, M. (2001a). Effet physique chez l'individu de l'idée de mort suggérée par la collectivité. Dans Sociologie et Anthropologie (pp. 313-330). Quadrige / PUF.

Mauss, M. (2001b). Esquisse d'une théorie générale de la magie (9e édition). Dans Sociologie et Anthropologie (pp. 3-141). Quadrige / PUF.

Mauss, M. (2001c). Les techniques du corps. Dans Sociologie et Anthropologie (pp. 365-386). Quadrige / PUF.

Mauss, M. (2001d). L’Ethnographie en France: Une science négligée, un musée à former. Revue européenne des sciences sociales, 1(49), 209-234.

Mauss, M. (2012). Leçon d'ouverture de Marcel Mauss donnée le 23 février 1931 (Archives familiales). Dans J.-F. Bert, L'Atelier de Marcel Mauss (pp. 249-264). CNRS Éditions.

Mauss, M. (2013). Sosyoloji ve Antropoloji (4. basım, Ö. Doğan, çev.). Doğu Batı Yayınları. 
Mauss, M., \& Murray O., S. (1989). A 1934 Interview with Marcel Mauss. American Ethnologist, $16(1), 163-168$.

Mauss, M., \& Philippe, B. (1979). L'œuvre de Mauss par lui-même. Revue française de sociologie (20-1), 209-220.

Moebius, S. \& Nungesser, F. (2013). La filiation est directe : Der Einfluss von Marcel Mauss auf das Werk von Claude Lévi-Strauss. European Journal of Sociology, 54, 231-263.

Tarot, C. (1999). De Durkheim à Mauss, l'invention du symbolique : Sociologie et science des religions. Editions La Découverte / M.A.U.S.S.

Tarot, C. (2003). Sociologie et anthropologie de Marcel Mauss. La Découverte.

Tarot, C. (2010/2). Un inconnu célébrissime: Marcel Mauss. Reveu de MAUSS, 36, 21-24. 
